\title{
The Part-Time Pay Penalty in a Segmented Labor Market
}

\author{
Daniel Fernández-Kranz \\ IE Business School \\ Núria Rodríguez-Planas \\ Universitat Autònoma de Barcelona, \\ IZA, FEDEA, and MOVE \\ First version: August 2009 \\ This version: May 2010
}

\begin{abstract}
This paper is the first to examine the implications of switching to PT work for women's subsequent earnings trajectories, distinguishing by their type of contract: permanent or fixedterm. Using a rich longitudinal Spanish data set from Social Security records of over 76,000 prime-aged women strongly attached to the Spanish labor market, we find that PT work aggravates the segmentation of the labor market insofar there is a PT pay penalty and this penalty is larger and more persistent in the case of women with fixed-term contracts. The paper discusses problems arising in empirical estimation (including a problem not discussed in the literature up to now: the differential measurement error of the LHS variable by PT status), and how to address them. It concludes with policy implications relevant for Continental Europe and its dual structure of employment protection.
\end{abstract}

Key words: Fixed-term and permanent contract, hourly wage levels and growth, prime-aged women, fixed-effects estimator, differential measurement error of LHS variable, underlying channels.

JEL classification: J13, J16, J21, J22, J31, J62, C23

We are extremely grateful to participants of $34^{\text {th }}$ Symposium of Economic Analysis at the Universitat de Valencia, the Second Workshop on Gender Economics at the Universidad de Granada, ZEW Workshop on Flexibility in Heterogeneous Labour Markets at Mannheim, and seminars at the Bank of Spain and the Universitat Pompeu Fabra for helpful comments. We also thank the extremely valuable suggestions and comments from two anonymous referees and the editor, Juan J. Dolado. Núria Rodríguez-Planas acknowledges financial support from the Spanish ministry of Education and Science (grant SEJ2006712), the Generalitat de Catalunya (grant SGR2005-712), and Barcelona Economics XREA - Program. Daniel Fernández-Kranz acknowledges financial support from the Spanish Ministry of Education and Science (grant ECO2009-07237). Finally, Núria Rodríguez-Planas is affiliated to IZA in Bonn, FEDEA in Madrid, and MOVE in Barcelona, and greatly appreciates their support. 


\section{Introduction}

In the light of the recent surge in PT employment in many industrialized countries, and the relative concentration of women in PT jobs (making the issue a major one in gender equality), many researchers have increasingly become interested in analyzing the hourly wage differential between PT female workers and their FT counterparts and its causes. ${ }^{1}$ To disentangle the channels through which the (raw) PT pay penalty emerges is the first step for designing policies which aim at improving the conditions of PT workers (Manning and Petrongolo, 2008). Given the policy relevance of this line of research, it comes as a surprise the little attention there has been, thus far, on the differential effect of PT work on wages across different population subgroups, as the underlying forces behind the PT pay penalty may differ drastically in different labor markets leading to distinct policy recommendations. ${ }^{2}$

At the same time, there is a growing concern among academics, politicians and practitioners, that the path of partial reforms taken by many Continental European countries, such as France, Germany, Portugal, Italy, and Spain, over the last three decades of maintaining strong employment protection for regular jobs while attempting at establishing more flexible but marginal labor market segments has resulted in a dual labor market. Thus, there has been a deepening segmentation of these labor markets with 'insiders' (those with permanent contracts), on the one side, enjoying high level of employment protection, decent jobs and generous benefits, and 'outsiders' (those with fixed-term contracts), on the other, having poor labor market perspectives and low

\footnotetext{
${ }^{1}$ See Jones and Long, 1979; Blank, 1990; Ermisch and Wright, 1993; Montgomery and Cosgrove, 1995; Jepsen, 2001; Wolf, 2002; Hu and Tijdens, 2003; Rodgers, 2004; Jepsen et al., 2005; Hardoy and Schøne, 2006; Manning and Petrongolo, 2008; and Connolly and Gregory, 2009, among others.

${ }_{2}$ A possible explanation for this is that most studies (especially in Europe) rely on relatively small sample sizes of individuals who work PT making difficult the heterogeneity analysis. We have identified the following exceptions: Mocan and Tekin, 2003, analyze the nonprofit sector dimension; O'Connell and Gash, 2003, focus on differences between skilled and unskilled workers; and Ferber and Waldfogel, 1998; Rodgers, 2004; Booth and Wood, 2008; Hirsch, 2005; O’Dorchai et al., 2007; and Mumford and Smith, 2007, study the gender dimension (or focus on male workers).
} 
remuneration. $^{3}$ Clearly, analyzing the PT / FT hourly wage differential and understanding the underlying channels behind the (possible) PT penalties in these two segments of the labor market ought to be of most relevance from policy making in countries with a high share of unemployment and stringent employment protection legislation. ${ }^{4}$ This is the central point of this article.

Our paper is the first to examine the implications of switching to PT work for women's subsequent earnings trajectories from the dual labor market employment protection perspective, by analyzing the PT pay penalty and its cause across two groups of workers, those with and without a permanent contract. We focus on adult women between 24 and 45 years old and strongly attached to the Spanish labor market and use a rich longitudinal dataset obtained from the Social Security records that covers employment history from 1996 to 2006, and has only recently been available to researchers in Spain. ${ }^{5,6}$

Our paper brings to light that PT work aggravates the segmentation of the labor market insofar the detrimental effects of PT work are considerably bigger and more persistent for workers under a fixed-term contract compared to workers with a permanent one. More precisely, we find evidence of a PT penalty both in wage levels and in wage growth of a greater magnitude for workers with fixed-term contracts than those with a permanent one. After accounting for workers' observable and unobservable characteristics, we find that PT women with permanent contracts have

\footnotetext{
${ }^{3}$ See Bentolila and Dolado, 1994; Blanchard and Landier, 2002; Dolado, et al., 2002; Cahuc and Kramarz, 2004; Beninger, 2005; Eichhorst, 2007; and Dolado, et al., 2007, among others.

${ }^{4}$ Note that in this paper we shall deal with two types of segmentation: (1) permanent contracts (primary) versus temporary contracts (secondary); and (2) FT (primary) and PT (secondary) employment.

${ }^{5}$ Although the data set covers employment history from 1985 to 2006, we focus our analysis on the 1996 through 2006 period because type of contract is not available prior to 1996. However, we shall use women's employment history back to 1985 to calculate variables such as labor market experience and tenure.

${ }^{6}$ Although several papers have used longitudinal data to estimate the PT pay penalty (Blank, 1998; Hirsch, 2005; and Booth and Wood, 2008, among others), very few have over a decade of data allowing them to observe women extended labor market history (see for instance, Connolly and Gregory, 2009).
} 
wages that are, on average, 9 log points lower and grow 2.9 log points less per year than wages of FT counterparts. For women with fixed-term contracts, the PT pay penalty is more than twice as large, 23 log points, and wages grow 3.9 log points less per year than wages of FT counterparts. To put the estimates of wage growth into context, their size ranges between one-and-a-half and twice the size of the estimated college premium on wage growth. Thanks to the richness of our dataset, our estimates control for workers' socio-demographic characteristics, employer's characteristics, workers’ previous employment history, and workers’ unobserved heterogeneity.

The paper also discusses problems arising in empirical estimation, and how to address them. In particular, one contribution of our paper is to uncover an empirical problem not discussed in the literature up to now: the differential measurement error of the LHS variable by PT status. We use an alternative dataset (the Time Use Survey), to compare contractual hours with actual hours worked and show that PT workers consistently work a greater number of hours in excess of contractual hours relative to their FT counterparts. ${ }^{7}$ The result of this measurement error in contractual hours is to bias upwards the hourly wages of PT workers (relative to FT workers) leading to underestimating the PT wage penalty. ${ }^{8}$ To address this problem, we follow two different strategies. First, we use imputed effective hours to obtain an estimate of the PT / FT wage differential in levels. Second, we focus our attention on the wage change as opposed to wage level, and drop from our sample of analysis the observations of wage change observed exactly when status changes. ${ }^{9}$ Assuming that differential measurement error by PT status is an individual-employment-status fixed-effect, our

\footnotetext{
${ }^{7}$ The measurement error in contractual hours can be explained by employers having an incentive to underreport contractual hours to reduce total labor costs, and being able to act upon it in a much easier way for PT jobs (since they are less protected by the law and the unions) than for FT jobs.

${ }^{8}$ As our data comes for Social Security records, we use contractual monthly wages and hours to calculate the hourly wages.

${ }^{9}$ For most (96\%) of our sample of individuals who switched to PT employment, we observe them several years in either status. Therefore individuals' attrition because of this restriction is practically negligible.
} 
approach circumvents the problem of differential measurement effect and informs us on whether the PT status also implies a penalty in the subsequent growth of wages.

Spain is a suitable case to investigate this issue because of the striking segmentation of its labor market. ${ }^{10}$ The Spanish unemployment rate has been extremely high (as much as one fifth of the labor force) for almost two decades (during the 1980s and 1990s), and it is currently, at 20\%, the highest in Europe. In addition, an important dual labor market developed after legislation changes in 1984, resulting in the economy with the highest rate of fixed-term contracts in Europe for the last two decades (over one third of all contracts are fixed-term contracts). Finally, the issue is particularly timely as the Spanish Prime Minister, following other industrialized countries' practices, is proposing to promote the use of PT work to fight unemployment, arguing that it will add flexibility in the labor market.

This paper is closer to Connolly and Gregory, 2009, (hereafter, CG) in that it examines the implications of switching to PT work for women's subsequent earnings trajectories using a long unbalanced panel and a fixed-effects 'within' estimator approach. Methodologically, our work differs from CG study in the following three ways: First, we estimate the differential PT pay penalty by type of contract. Second, we are able to distinguish between the PT pay penalty and the `motherhood pay gap’, as our data contains information on children in the household (whereas CG cannot distinguish between mothers and non-mothers). Third, we identify and address a methodological issue regarding differential measurement error in the dependent variable. While our findings for the primary labor market are consistent with those found by Connolly and Gregory, 2008 and 2009, and Manning and Petrongolo, 2008, in the UK and Hirsch, 2005, in the US, our work brings to light that in addition to the

\footnotetext{
${ }^{10}$ See for instance, Bentolila and Saint-Paul, 1994; Adam, 1996; Amuedo-Dorantes, 2000; GaldónSánchez and Güell, 2003; and Güell and Petrongolo, 2007, among others.
} 
conventional channels behind the PT penalty, workers from the secondary labor market suffer a further unexplained loss due to the PT status switch itself, in addition to experiencing negative returns to PT work. ${ }^{11}$

The paper is organized as follows. The next section presents an overview of the literature. Section III describes the Spanish economic and institutional background. Section IV presents the data and the descriptive statistics. Section V explains the methodological approach, analyzes the results, and discusses sensitivity analyses. Section VI concludes with a discussion on policy implications. An additional Appendix, which can be find in the authors' web page, provides further information on the data and detailed results on the sensitivity analyses.

\section{Literature on PT Earnings Penalty}

Many researchers have increasingly become interested in analyzing the hourly wage differential between PT female workers and their FT counterparts. While the earliest studies focused on the US (Jones and Long, 1979; Blank, 1990) and the UK (Ermisch and Wright, 1993), the more recent literature has evaluated the PT pay penalty in many industrialized countries, such as Australia (Rodgers, 2004), Belgium (Jepsen, 2001; and Jepsen et al., 2005), Norway (Hardoy and Schøne, 2004), The Netherlands (Hu and Tijdens, 2003); and West Germany (Wolf, 2002), among others. Most studies find a negative unadjusted PT wage gap (a PT pay penalty), the magnitude of which differs substantially across the different countries. In some studies_-such as, Rodgers, 2004; Jepsen, 2001; Jepsen et al., 2005; Hardoy and Schøne, 2004; Muñoz de Bustillo Llorente et al., 2008; and Manning and Petrongolo, 2008-, the PT pay penalty vanishes or becomes small when controlling for differences in workers and job

\footnotetext{
${ }^{11}$ In the primary labor market, we find that the PT penalty is fully explained by the change of employer, negligible returns to PT work experience, and job characteristics.
} 
characteristics (especially education and occupation). In other studies (Gallie et al., 1998; Gornich and Jacobs, 1996; Rosenfeld and Kalleberg, 1990), a wage gap remains and this unexplained part also shows considerable cross-country variation. Finally, in a third group of studies, a PT pay premium is found (Booth and Wood, 2008; Pissarides et al., 2005; and Pagán Rodríguez, 2007). ${ }^{12}$

While some of the differences in the results are explained by countries' institutional and cultural differences, and the amount of information available on workers, jobs, and labor market characteristics in the different datasets used; several identification problems within this literature are difficult to overcome. Most of this literature compares the hourly wages of PT female workers with those of FT female workers after controlling for all observable characteristics, acknowledging that unobserved heterogeneity may still prevail, as women deciding to work PT may have different tastes and preferences about work than do women who work FT. As Hakim, 1997, explains, while some women are committed to careers in the labor market, a second group of women are qualitatively different since they give priority to their domestic roles and activities, do not invest in what economists term 'human capital' even if they acquire education qualifications, transfer quickly and permanently to parttime work as soon as a breadwinner husband permits it, choose undemanding jobs 'with no worries or responsibilities' when they do work, and are hence found concentrated in lower paid and lower grade jobs which offer convenient working hours with which they [are] satisfied. (p. 43). If there are unobserved quality differences between PT and FT workers, results from cross-sectional studies of the PT wage effect will reflect an omitted variable bias. Nevertheless, many of the studies on the PT wage effect have been estimated on cross-sectional samples-see, for example, Simpson,

\footnotetext{
${ }^{12}$ A detailed discussion on the few studies that have analyzed the PT hourly wage differential in Spain can be found in the next section, which describes the Spanish economic and institutional background (Section III) and in the results section (Section V.1).
} 
1986; Blank, 1990; and Hotchkiss, 1991; Ermisch and Wright, 1993; Rodgers, 2004; Pagán Rodríguez, 2007; Manning and Petrongolo, 2008; Mumford and Smith, 2008, among others.

One way to address the unobserved heterogeneity problem is to use panel data and to estimate a fixed-effects-'within' estimator, in which case, the effect of PT on wages is identified through those workers who switch status (see Booth and Wood, 2008; and Connolly and Gregory, 2009). ${ }^{13}$ While having important advantages, longitudinal analysis is not without shortcomings. A frequent problem arises when there is a small sample size of switchers, especially due to the infrequent transitions between FT to PT work and vice-versa, questioning the external validity of the results. In addition, measurement errors of hours and wages, which are common in this literature (Altonji 1986; Bound et al., 2001), bias OLS estimates towards zero and magnify the attenuation bias in a fixed-effects context (Aaronson and French, 2004; Manning and Petrongolo, 2008).

Given that most studies use worker' survey data, measurement errors of key variables is a frequent concern in this literature. For instance, the OECD, 2002, warns about the possibility of having measurement errors in the survey stemming from the fact that the interviewed persons provide direct information about their own wages, rather than their employers, as is the case with matched employer-employee data or social security records. Others have raised similar concerns (see for instance, Pissarides et al., 2005; Mocan and Tekin, 2003; or Buligescu et al., 2009). Most recently, Buligescu et al., 2009, find that reported actual working hours, which are usually observed only for one week, show considerable dispersion and are likely to induce spurious negative correlation between working hours and the calculated wage

\footnotetext{
${ }^{13}$ Alternatively, Hirsch, 2005, uses multiple short panels with two observations per worker (one year apart) to estimate the effect of switching between FT and PT status on wage changes.
} 
rate. They argue that it is better to use contractual hours as they do not tend to vary as much from week to week. Some efforts to reduce the effect of measurement error in reported hours worked (and consequently PT status) include instrumenting such variables with their lags. However, the results indicate that the instruments do not always seem to work as they are fairly similar to OLS estimates for some of the countries (Pissarides et al., 2005).

Another important identification problem is the danger of reverse causation: maybe it is low wages that 'cause' PT work, not PT work that 'causes' low wages. This problem is usually addressed by using an instrumental variables strategy. However, for this technique to work well requires a variable that affects propensity to work PT but does not have a direct effect on earnings. Unfortunately, such a variable is extremely difficult to find. And albeit children and marital status are frequently used as variables affecting the decision to work PT but not the wages earned—see Ermisch and Wright, 1993; Blank, 1998; Manning and Petrongolo, 2008, among others-, it is well established in this literature that "this is a very strong assumption that may not, in reality, be any better than the exogeneity assumption that this is supposed to replace” (Manning and Petrongolo, page F33, Economic Journal 2008). Aaronson and French, 2004, are the only ones that we know of to use an alternative instrument for worked hours, the work disincentive of the Social Security system. They are able to isolate exogenous shifts into PT employment resulting from changes in Social Security rules for older males. ${ }^{14}$

\footnotetext{
${ }^{14}$ At ages 62 and 65, individuals face incentives to reduce their work hours. During their sample period, most individuals age 62 and older are eligible for social security benefits but face an earnings test until age 69. Above the social security earnings test threshold level, individuals face a high marginal tax rate on earnings. Between ages 62 and 64, benefits lost through the earnings test are replaced in the form of higher benefits in the future, resulting in about a dollar of higher benefits in present value in the future for every dollar lost through the earnings test. However, if individuals are liquidity constrained, it may not be until age 62, when the early retirement provision of the social security rules applies, that they will have sufficient financial resources to reduce their work hours. After age 65, benefits lost through the social
} 
In our paper, we account for worker unobserved heterogeneity by exploiting a rich longitudinal dataset that covers employment history from 1985 to 2006, and has only recently been available to researchers in Spain. In addition, as our data comes for Social Security records, we use contractual monthly wages and hours to calculate the hourly wages, eliminating the problem of measurement error due to recall bias or nonresponse. We do not model selection into PT employment. Therefore, we do not strictly identify the causal impact on wages or wage growth of working PT. However, considering that longitudinal estimates more closely approximate average treatment effects among the treated than among random draws from the population (Hirsch, 2005), we believe that our estimates address some of the issues raised in this literature and bring new evidence on the situation of PT workers in segmented labor markets in general, and in Spain, more specifically.

\section{Economic and Institutional Background}

Most of the existing literature on PT employment uses data from the Netherlands, UK, US, or Australia where PT accounts for a very high percentage of overall female employment and where the incidence of female temporary or fixed-term employment is relatively low. Table 1 shows statistics for some of these countries and illustrates that Spain is among the countries with a lower incidence of PT work combined with an extremely high incidence of fixed-term employment (OECD, 2008). These figures highlight that the role of PT employment in Spain may differ given the unique specificities of its labor market. Below, we discuss the institutional background on PT and fixed-term employment in Spain.

security earnings test result in only small increases in future benefits. Therefore, the social security earnings test results in a strong incentive to reduce work hours by age 65 . 
The two most common forms of flexible work arrangements (fixed-term contracts and PT work) have evolved quite differently in Spain over the last two decades. Both types of contracts were first regulated by law in 1984 with the objective of adding flexibility and promoting employment in a rigid labor market with stringent employment protection legislation and high levels of unemployment. While fixed-term employment soared, the growth in PT employment was modest, at most. As a result, since the early 1990s, fixed-term employment represents one third of the Spanish labor force (by far, the highest share among European countries), whereas the share of PT employment is below one tenth of the labor force (far from the EU average of 18\%).

\section{Fixed-Term Contracts}

Prior to 1984, most contracts in Spain were permanent contracts. With such contracts, the costs of dismissing a worker were high (up to 45 days of wages per year worked if the worker appealed to Court and the dismissal was declared “unfair”, with a limit of 24 months' wages). ${ }^{15}$ In 1984, in a context of high unemployment and given that an across-the-board reduction of dismissal costs was politically unfeasible, the use of temporary contracts was liberalized. As such, fixed-term contracts for regular activities entailed much lower severance payments than permanent contracts (initially of 12 days per year worked, zero if the firm waited until expiration), and their termination could not be appealed to labor courts (in contrast with their permanent counterpart). However, temporary contracts could only be used up to a maximum of three consecutive years.

The surge of fixed-term contracts began to be questioned in the late-1980s when experts started to advise against the risk of segmentation with "good” (permanent) jobs and "bad” (fixed-term) jobs—Segura et al., 1991; Bentolila and Dolado, 1992; Jimeno and Toharia, 1993; and Dolado et al., 2002. The concern was that the Spanish labor

\footnotetext{
${ }^{15}$ Izquierdo and Lacuesta, 2006, and Galdón-Sánchez and Güell, 2003, estimate that between $72 \%$ and $75 \%$ of cases that arrived to court were declared "unfair" by Spanish judges.
} 
market would become a dual labor market with workers with fixed-term contracts holding unstable, low protected and poorly paid jobs, while workers with indefinite contracts enjoyed protection and presumably also higher wages. According to Bover and Gómez, 2004, between 1985 and 1994, over 95\% of all new hires were employed through temporary contracts and the conversion rate from temporary to permanent contracts was only around $10 \% .^{16}$

The reforms of 1994, 1997, 1999, and 2001 aimed to enhance the use of permanent contracts and reduce its cost. While the 1994 reform tried to limit the use of temporary contracts through ineffective regulation, the more recent reforms increased the incentives for firms to hire workers in certain population groups using permanent contracts. $^{17,18}$ However, these reforms were quite unsuccessful at reducing the share of temporary contracts in the labor force-see Kugler et al., 2002, and Dolado et al., 2002. Moreover, Güell and Petrongolo, 2007, find that the conversion rate of fixedterm contracts into permanent ones has decreased over time, as it has gone down from $18 \%$ in 1987 to $5 \%$ in 1996 , reflecting the fact that employers use fixed-term contracts more as a flexible device to adjust employment in the face of adverse shocks than as stepping stones towards permanent jobs. Consistent with this finding, Dolado et al., 2002, find that a large fraction of temporary workers have been hired under fixed-term contracts while other types of temporary contracts (probationary or seasonal jobs), which are more representative in other European labor markets, have remained

\footnotetext{
${ }^{16}$ Once workers have a permanent contract, they will rarely switch to a temporary one, unless they become unemployed. For example, in our dataset women that have a permanent contract at $t$ have a probability of $96.9 \%$ of having a permanent contract at $t+1$ if they continue to be employed.

${ }^{17}$ In 1994 new regulations limited the use of temporary employment contracts to seasonal jobs. In practice, employers found ways to get around this restriction and continued to hire workers under temporary contracts for all types of jobs and not just for seasonal jobs.

${ }^{18}$ For instance the 1997 reform reduced unfair dismissal costs by about $25 \%$ and payroll taxes between $40 \%$ and $90 \%$ for newly signed permanent contracts for workers under 30 years of age, over 45 years of age, the long-term unemployed, women under-represented in their occupations, and disabled workers. In addition, this reform reduced unfair dismissal costs by about $45 \%$ and payroll taxes by $50 \%$ for conversions of temporary into permanent contracts for all age groups.
} 
relatively unimportant in Spain. These authors also find that, since the regulation of fixed-term contracts in Spain in 1984, worker and job turnover have increased considerably. Not surprisingly, several authors have found that the likelihood of transiting into unemployment is considerably higher among workers with fixed-term contracts than those with permanent ones (Güell and Petrongolo, 2007; García-Ferreira and Villanueva, 2007; and Barceló and Villanueva, 2010). As such, Barceló and Villanueva, 2010, estimate that for a given year the probability of entering an unemployment spell is 8 percentage points higher for workers with fixed-term contracts (10\%) than those with permanent ones (2\%). Amuedo-Dorantes, 2000, also finds that temporary work spells in Spain are unlikely to end in permanent jobs, regardless of workers' tenure, and that temporary work is more likely to become a trap than a bridge to permanent employment. Another piece of evidence suggesting that the labor market of temporary workers is a secondary labor market in Spain is provided by Dolado et al., 1999, who estimate that the probability of receiving free or subsided on-the-job training was $22 \%$ lower for workers under fixed-term contracts than for workers under permanent contracts, and by Jimeno and Toharia, 1996, who also suggest that temporary employment increases work accidents, which happen to be three times larger for workers under fixed-term contracts than for workers under permanent contracts. Finally, Amuedo-Dorantes, 2000, also provides evidence that temporary contracts are less desirable then permanent ones in Spain. This author estimates that $85 \%$ of temporary workers in Spain in 1996 are involuntarily holding a temporary job because of their inability to find a permanent job. In addition, she finds that only $0.4 \%$ of temporary workers claim that they have been seeking a temporary job. 


\section{Part-Time Work}

PT work in Spain has traditionally been a second-best job because of its unfortunate regulation. Prior to the 1980s, PT work in Spain heavily penalized workers in terms of higher social security costs and was only legal for certain types of workers considered at-risk of social exclusion, such as disabled workers, first time job seekers, workers over 40 years of age or with family responsibilities, and the long-term unemployed. The 1980 Worker's Act (Estatuto del Trabajador) removed the social security costs' penalty, and the 1984 reform eliminated the hiring restrictions and legalized (for the first time) the conversion from FT to PT contracts. However despite these changes, PT employment remained modest, hovering around $5 \%$ of the labor force. It is not until the mid-1990s with the economic crisis and the 1994 reform that aimed at increasing PT work as a flexible work arrangement by reducing the social rights of some PT workers (those working less than 12 hours per week or less than 48 hours per month), that PT employment rose to 8\% of the labor force. Four years later, the 1994 changes were undone as the Spanish PT regulation converged to that of the EU, but PT remained stable around 9\% of the labor force--and far from the EU average.

PT work is not only less frequent among female workers in Spain than in the neighboring European countries, but it is also less stable. For instance, Buddelmeyer et al., 2005, estimate a year-to-year transition matrix between different employment status and find that only half of women working PT in Spain, over the 1994 through 1999 period, remain in such status one year later-compared to $72 \%$ on average in the EU-11 countries. Where are the rest of the PT women one year later? According to Buddelmeyer et al., 2005, in Spain one fifth end up working FT, another one fifth end up out of the labor force and the other one tenth enter unemployment. ${ }^{19}$ These figures

\footnotetext{
${ }^{19}$ Muñoz de Bustillo Llorente et al., 2008, find similar results for the period 1987 through 1995.
} 
contrast sharply with those from the EU-11 average where 14\% move to FT work, 11\% leave the labor force and 3\% enter unemployment, and raise caution into seeing PT jobs as stepping stone into good jobs in Spain as 35\% of women working PT exit employment within a year (compared to only 14\% in the EU-11). Consistent with these findings, Fernández-Kranz and Rodríguez-Planas, 2010, find that less than one fourth of the PT employment spells that initiate from non-work (defined as unemployed or out of the labor force) end with FT employment over the 1996 through 2006 period, while the other $75 \%$ end up exiting employment. ${ }^{20}$ These authors find that $86 \%$ of all PT spells over this period initiated from non-work, whereas only $14 \%$ originate from FT work (of which $8 \%$ went into PT and back to FT, and the other 6\% transitioned from FT work to PT to out of work.)

Further evidence supports the hypothesis that those in PT in Spain are in secondary employment. PT workers are more likely to be working under a temporary contract than a permanent one. For instance, pooling Labor Force Survey (LFS) data from 1999 to 2009, we find that the likelihood of having a fixed-term contract almost doubled for PT workers than for FT ones (52,19\% versus 28,67\%). Alternatively Table 2 shows that PT work is much more frequent among fixed-term contracts than permanent ones, both for males and females. For instance, while the share of women with fixed-term contract that work PT doubles that of women with permanent contract (29.85\% compared to $15.67 \%$ ), for males this likelihood is more than four times as big (6.77\% compared to 1.45\%). Moreover, similar to other countries, PT work is concentrated among certain industries-especially services, such as, retail sales, janitors, real state, restaurants, education, and other social and personal services-, and

\footnotetext{
${ }^{20}$ The average PT spell for these workers was 16 months for those who end up in FT work and 10 months for those who end up exiting employment.
} 
low-skilled occupations, such as non-qualified occupations or non-professional whitecollar jobs (Muñoz de Bustillo Llorente et al., 2008).

Another characteristic of PT work in Spain is that it is highly involuntary. The Spanish LFS asks workers the reasons for working part-time. Using pooled data from the 1999 through 2009 LFS, we find that more than half of PT workers $(52.66 \%$ of women and 58.64\% of men working PT) are doing so involuntarily, either because they could not find a full-time job (27.88\% of women and $28.25 \%$ of men), or because the type of work activity they were engaged in required such an arrangement (24.78\% of women and $30.39 \%$ of men). While $40 \%$ of women and $32.37 \%$ of men working PT reported doing so voluntarily, the reasons they gave differed by gender. ${ }^{21}$ As many as 22.09\% of women working PT (but only $2.35 \%$ of their male counterparts) reported choosing such an arrangement because of family reasons. In contrast, $17.91 \%$ of women and $30.02 \%$ of men reported choosing to work PT because they were studying, were sick, or had some other type of disability. To put these numbers into context and allow comparison with other European countries, we have used the 2005 Work Orientations module from the Social Survey Program(ISSP) to estimate the percentage of workers who would prefer a FT job, by PT/FT status. The estimates, shown in Figure 1, are striking. While in Nordic, Liberal or Continental Europe less than one fourth of workers in PT jobs would prefer working FT, in Spain almost two thirds of FT workers would prefer to have a FT job.

It is also worthwhile to explore whether the voluntariness into PT work varies not only by gender, but also by type of contract. Table 3 explores this issue using the 1999-2009 Labor Force Survey data. Table 3 shows that the share of involuntary PT work (either because they could not find a FT job or because their job required them to

\footnotetext{
${ }^{21}$ A small fraction of PT workers either did not respond to this question.
} 
do so) is larger among fixed-term contracts than permanent ones, and that this is specially so for women. For instance, while the proportion of women involuntarily working PT is 17 percentage points greater for those with a fixed-term contract (65.11\%) than for those with a permanent one (47.93\%), this difference is only 4 percentage points greater among males (62.99\% versus 59.26\%). Another interesting finding from Table 3 is that the fraction of women working PT because of family reasons (that is, taking care of their children or an elderly) is more than three times higher for women with permanent contracts (28.60\%) versus a fixed-term ones (12.48\%), suggesting that while PT work may be a cultural choice in the primary labor market, it is not necessarily so in the secondary market.

As explained with more details in Section IV, in our analysis we shall focus on women strongly attached to the labor force to reduce a potential problem with PT voluntariness due to non-market responsibilities. In addition, the Appendix also presents the analysis by whether the women have family responsibilities (measured by presence of children in the household) or not, to explore whether our results are driven mainly by mothers. As explained, our results are robust to such analysis.

\section{Feminization of These Types of Work Arrangements}

In Spain, women are over-represented in both types of work arrangements, parttime and fixed-term. According to the 1999 through 2009 Labor Force Survey, we find that $33.62 \%$ of contracts among women in Spain are fixed-term compared to $29.34 \%$ among men, and $20.54 \%$ of women work in PT jobs compared to $3.20 \%$ of men. While women's role in home production may imply that women have stronger preferences than men for PT jobs, this does not necessarily imply gender differences for fixed-term contracts (as a permanent contract is at least as desirable as a temporary one, given that it would commit the firm rather than the worker to costly procedures in case of 
separation). Using data from the 1994 through 1999 waves of the European Community Household Panel Survey, Pissarides et al., 2005, find evidence suggesting that the unequal allocation of genders across fixed-term contracts and PT work in Spain stems from employer discrimination as opposed to workers' comparative advantage. They find that, after controlling for comparative advantages by conditioning the likelihood of being in involuntary PT work on human capital and family characteristics, single women in Spain are 10 percentage points more likely to be involuntary PT workers than single men. Similarly, they find that fixed-term contracts are 4 percentage points more frequent among single women than single men in Spain, and that strong family ties reinforces this tendency, with married women with children being about 9 percentage points more likely than married men to hold a fixed-term contract. In addition, exploring workers' preferences, these authors do not find evidence that women are particularly happier (or less unhappy) than men on PT jobs or with fixedterm contracts, as they find that PT jobs (fixed-term contracts) in Spain tend to reduce both males' and females' overall job satisfaction by $16 \%(25 \%){ }^{22}$

\section{Evidence of Wage Differentials for these Types of Work Arrangement}

The evidence on wage differences by type of contract or PT status has been scarce in Spain (mainly due to the lack of large databases containing individual information on wages until recently), and based on cross-sectional analysis. Given that wages are set by collective agreements and that these do not allow workers to be paid differently because of type of contract, it seems reasonable to think that employers do not discriminate against workers by type of contract. Despite this fact, several empirical studies find that permanent workers earn around 10\% more, for men, and about 5\% more, for women, after controlling for observed heterogeneity in personal and job-

\footnotetext{
${ }^{22}$ While many studies from developed countries find a preference for part-time work among women (Booth and van Ours. 2008 ; Gregory and Connolly, 2008 ; Van Praag and Ferrer-i-Carbonell, 2004), no such effect is found in East Germany or France (Clark and Senik, 2006) or Honduras (López et al., 2009).
} 
related characteristics and for selection into type of contract (Jimeno and Toharia, 1993; Hernanz, 2002; and De la Rica, 2004). Moreover, there is evidence that workers with fixed-term contracts segregate into low-paying firms and occupations (De la Rica, 2004). According to Dolado et al., 2002, "the previous evidence also points out that the wage gap is associated with the fact that employers tend to 'under classify' temporary workers in the occupational categories probably to cut total labor costs in view of the higher wage-pressure on permanent contracts caused by union pressure. Therefore, although temporary workers may be doing a similar job, their wages are lower than those of similar workers with permanent contracts."

Turning to the evidence on PT / FT wage differential, the evidence on wage differences between PT and FT workers in Spain has found that there is an 'unexpected' (in the light of the anecdotal evidence and job satisfaction indicators) wage premium to working PT (Pagán Rodríguez, 2007), or no effect (Pissarides et al., 2005, and Muñoz de Bustillo Llorente et al., 2008). However, failure of correcting for unobserved heterogeneity and measurement problems raise caution before taking these estimates at face value—as acknowledged by Pissarides et al., 2005—, and explained with more details in Section V.

\section{The Data and Descriptive Statistics}

We use data from the 2006 wave of the Continuous Sample of Working Histories (hereafter $\mathrm{CSWH}$ ), which is a $4 \%$ non-stratified random sample of the population registered with the Social Security Administration in 2006. ${ }^{23}$ The CSWH consists of nearly 1.1 million individuals and provides the complete labor market history of the

\footnotetext{
${ }^{23}$ This includes any person that has either contributed to the Social Security or has received a pension or unemployment benefits from the Social Security during 2006. These data are extracted from administrative records from the Social Security, the Municipal Registry of Inhabitants, and the Spanish Internal Revenue Service. For a description of the CSWH and the sampling strategy, see Argimón and González, 2006.
} 
selected individuals back to $1967 .{ }^{24}$ It provides information on: (1) socio-demographic characteristics of the worker (such as, sex, education, nationality, province of residence, number of children in the household and their date of birth); (2) worker's job information (such as, the type of contract—fixed-term versus permanent contract—, the PT status, the occupation, and the dates the employment spell started and ended, and the monthly earnings); (3) employer's information (such as, industry-defined at the three-digits Spanish classification code or NACE—-, public versus private sector-, the number of workers in the firm, and the location—at the province level). Although not reported in the CSWH, other variables such as working experience (in FT and PT work) and tenure can be easily calculated. In addition, information on the individual's education level, and the number and date of birth of children living in the household at the time of the interview (including own natural, adopted, step and foster children) is also available in the Spanish Municipal Registry of Inhabitants, which is matched at the person level with the Social Security records.

Because the CSWH does not have reliable information on type of contract prior to 1996, our analysis focuses on the years 1996 to 2006 . However, we use information back to 1967 to calculate variables such as workers’ experience and tenure. Therefore, although our PT penalty analysis focuses on work histories from 1996 to 2006, we use information on the workers' employment experience (in FT and PT) and tenure back to 1985.

Following CG, we restrict our sample to women whose full labor market history to date can be observed. We focus our analysis on wage and salary workers, that is, we

\footnotetext{
${ }^{24}$ We have information on the dates the employment spell started and ended, but for those not working we do not know whether this is because they are studying, they are unemployed or another reason (the unemployed appear as such in the dataset only as long as they receive unemployment benefits from the Social Security but not if they are not eligible for such benefits). . Therefore, we record spells of nonwork as the time the person is not employed.
} 
exclude from the analysis self-employed individuals. ${ }^{25}$ We confine our selection to

birth cohorts between 1961 and 1978. In addition, we restrict women in our sample to

be aged between 24 and 45 years. The reason for dropping women younger than 24

years old is that we want to eliminate part-time work by students. In addition, we confine our analysis to women living in households of five or fewer members (96.5\% of the sample). The reason for restricting our attention to women 45 and younger living in households of five or fewer members is that we want to have accurate information on the number and age of children, which is unavailable in the CSWH but can be obtained from the information about the household composition as reported by the Spanish Municipal Registry of Inhabitants. ${ }^{26}$ Finally, because we want to confine the analysis to women with a strong attachment to the labor force, we further restrict our sample to women who record at least three years in wage and salary work after having worked at least one year FT (this is the same restriction as the one used by CG). ${ }^{27}$

This sample selection results in an unbalanced panel of 591,063 observations on 76,025 women, of which 16,469 (21.66\%) are observed working PT at some point in

\footnotetext{
${ }^{25}$ If the worker held more than one job, the analysis focuses on her main job, defined as the job in which the worker has a permanent contract-if she has one-, and in the case of multiple jobs with the same type of contract, the one for which the individual worked the largest number of days in a given year.

${ }^{26}$ Although we know who lives in the household and their age, we do not know their relationship with the respondent in the CSWH. According to Lacuesta and Fernandez-Kranz, 2009, the information on family composition is reliable (relative to Census data) for the sub-population of women under 45 years old and for those living in small households. However, for older women and for women living in large households, the data becomes noisier as it is unclear whether the younger person in the household is a descendent or just a roommate.

${ }^{27}$ By doing so, we reduce the possibility that our results are driven by the fact that PT workers are mainly poorly skilled workers who have difficulties remaining employed. To verify this, we compared the descriptive statistics of women strongly attached to the labor force (the sample used in the paper) to the same population prior to applying the restriction of strongly attached to the labor force (tables available from authors upon request). As expected, the restriction of "strongly attached to the labor force" eliminated a large fraction of part-timers-as many as $46 \%$ (45\%) of women working with a permanent (fixed-term) contract in 2006-, compared to the fraction of full-timers that was dropped-3\% and $16 \%$ of women working with a permanent and a fixed-term contract, respectively. Moreover, restricting the sample to those women strongly attached to the labor force raised the average education level of the women in the sample (especially among those who were working PT), lead to higher average experience levels and increased the proportion of women in white-collar jobs and in the manufacturing and trade sectors (while reducing the proportion of women working in the services sectors or the proportion of immigrant workers). Finally, the labor-force-attachment restriction lead to higher average wages (despite the fact that women fully attached to the labor force were younger).
} 
time between 1996 and 2006 as shown in Table 4. The percentage of women who switch to PT at some point in time is higher if they are working with a fixed-term contract $(28.13 \%)$ than if they are working with a permanent contract $(18.68 \%)$. Although our econometric analysis focuses on the time period between 1996 and 2006, individuals are in the CSWH between 3 and 21 years, and for an average of 8 years.

Table 5 presents descriptive statistics of the key covariates for the year 2006. The main focus of the present study is to analyze how the hourly wage trajectories vary by FT status and by contract type (fixed-term versus permanent). The data are therefore divided in four groups, classified by FT status and type of contract. $^{28}$ Following most of the European literature, we classify a worker working PT if she works 30 hours or less each week, and FT if she works 31 or more hours each week. Among the sample under study, we find that those with permanent contracts represent about two thirds of the sample. In addition, the percentage of women working in PT employment moves around one tenth of the sample, with a slightly higher share among those women working with fixed-term contracts (11\% versus $9 \%)$.

When comparing the variables for women working in PT versus FT jobs, Table 5 shows that PT workers have lower (raw) hourly wages and their (raw) hourly wage grows at a lower rate than FT workers. ${ }^{29}$ However, this cannot be used as a reliable estimate of the pay penalty that a given woman would suffer if she changed from FT to PT status because women working PT are very different from those working FT, as found in the subsequent rows of this table. For instance, we observe that PT workers are less-educated, older and more likely to have children of all ages than FT workers. Looking at employer differences across the two groups, women in PT employment are

\footnotetext{
${ }^{28}$ Although one individual can appear under different categories in different waves of the panel, it should be noted that these four categories are mutually exclusive.

${ }^{29}$ Our measure of pay is hourly earnings, calculated as annual earnings excluding overtime divided by total contractual hours, deflated by the 2006 price deflator.
} 
concentrated in the private sector, smaller firms and blue-collar occupations (relative to FT workers). These findings suggest that PT workers may segregate into low-paying firms and low-paying jobs. Finally, the years of experience into FT and PT work highlight that there is high persistence into both FT / PT status-this result has also been found in other countries by Blank, 1998; Buddelmeyer et al., 2005; and Connolly and Gregory, 2008, and 2009. Overall the observed differences for PT versus FT workers hold across the two types of contract. ${ }^{30}$

Compared to other datasets, our data has several advantages. First, the CSWH is a very large sample, which is important because PT work and switching from FT to PT (and vice-versa) is a relatively infrequent event, and more so when we focus the analysis on women strongly attached to the labor market. Second, the CSWH provides the complete labor market history for those women registered in the Social Security Administration in 2006, for up to 21 years. Although the restriction that information on type of contract is available reduces the length of women's earnings trajectories to up to ten years, it is still a non-negligible length of time. Third, it contains reliable information on monthly earnings, tenure, experience in FT and PT work, and change of employer, as the information comes directly from the payroll records. Measurement error due to recall bias or self-reporting for these key variables is minimized with this data set. Similarly, non-response is not an issue. Fourth, the dataset has rich information on individual characteristics, including education, age, ethnicity, marital status, and number and age of children in the household.

One of the short-comings of the CSWH is that it contains only information on individuals working in the formal sector. While Izquierdo et al., 2010 find that, compared to the Labor Force Survey, these dataset offers an accurate picture of the

\footnotetext{
${ }^{30}$ It is worth highlighting that women with a fixed-term contract have much less in the way of FT employment experience than those on FT or PT permanent contracts.
} 
formal sector in Spain, Ramos Muñoz, 2007, find that some differences exists for youth, females and foreigners due to the fact that the CSWH does not account for the informal sector. For this to be a problem in our study, we would need to argue that the incidence of the informal sector is greater among PT workers than FT workers, which seems plausible. Unfortunately, there is little we can do about this. That said, it is important to keep in mind that the bulk of our analysis focuses on the time period 1996 through 2006, which was mainly a period of economic expansion, reducing the relevance of the informal sector. Most importantly, our analysis focuses on women strongly attached to the labor force (and these women tend to work in the formal sector of the economy).

\section{Methodology and Results}

Our objective is to exploit longitudinal data in Spain to analyze the direct consequences of PT employment on subsequent earnings, earnings growth, and career trajectories. Because of the striking segmentation of the Spanish labor market, we analyze the PT penalty by type of contract and explore the effectiveness of job protection into reducing the potential PT penalty.

\section{V.1. PT log hourly wage differential}

We begin our analysis by estimating the average effect of working PT on the hourly wage level. Table 6 presents our estimates using a variety of approaches. For ease of the exposition, we use a simple dummy variable approach to measure the log hourly wage differences associated with PT status, conditional on controls. ${ }^{31}$ We begin by estimating the following equation using pooled OLS:

\footnotetext{
31 This approach is similar to the one used by Hirsch, 2005; Manning and Petrongolo, 2008, and CG, among others. Earnings function parameters differ between PT and FT status, but the gaps in the wage
} 


$$
L n W_{i t}=X_{i t} \beta+\theta P T_{i t}+\phi_{i}+\mu_{i t}
$$

Here, $\operatorname{Ln} W_{i t}$ is the natural $\log$ of real hourly earnings of individual $i$ at year $t ; X_{i t}$ is a vector of individual and job characteristics for individual $i$ at time $t$, with $\beta$ the corresponding coefficient vector (including an intercept). Because there has been much debate on whether variables that control for employer characteristics or change in occupation or employers ought to be included in the specification (see discussion below), we present alternative specifications to evaluate the robustness of the results. $P T_{i t}$ is a binary variable equal to one if the worker's principal job is PT in year $t$. The error term includes both a random component $\mu_{i t}$ with mean zero and constant variance, and a worker-specific fixed effect $\phi_{i}$. All regressions use the Huber/White estimator of variance and allow for observations not being independent within cluster-individuals. Regression (1) is estimated for the whole sample (panel A), and separately for workers with a fixed-term contract (panel B) and those with a permanent contract (panel C).

While it is true that our specifications do not account for selection by type of contract and by PT status, by controlling for the number and age of children and education, on the one hand, and employer characteristics, on the other, we are de facto controlling for the same information that many researchers have controlled for when using an instrumental variable approach correction. In the case of selection into FT/PT employment, most researchers use family composition variables to identify participation into PT employment (Blank, 1998; Pissarides et al., 2005) arguing that these variables do not explain wages. ${ }^{32}$ Similarly, in the case of selection by type of contract, researchers use employer's characteristics, such as private versus public sector

estimated using the dummy variable approach differ little from those based on separate equations by PT status, and evaluated at the means.

${ }^{32}$ To identify participation into PT work in Spain, Pagán Rodríguez, 2007, uses age, level of education, marital status, number of children 5 years old or younger, number of children between 6 and 12 years old, region and household income. He finds evidence of sample selection among women working PT (but not among those working FT). 
or firm size. ${ }^{33}$ We find the assumption that these variables explain participation but not wages (or wage growth in the next section) difficult to believe and, therefore, prefer using the information directly in the wage equation, acknowledging that selection into the different types of jobs cannot be corrected, although unobserved heterogeneity is accounted for with the fixed-effects specification. Also, as discussed in the Section V.3, we have addressed the issue of endogeneity of type of contract implementing two alternative IVs commonly used in the Spanish literature and have found that overall our results are robust to such correction (see Appendix Tables A.4 and A.5).

Analyzing first the pooled OLS estimates for the whole sample (first row of panel A), the estimate headed "unadjusted" shows that the log hourly earnings of PT women are, on average, 11 log points less than the log hourly earnings of FT women. The subsequent columns estimate the average PT hourly wage differential adding additional controls. For instance, the second column shows that the PT penalty falls to 3 log points once we control for women socio-demographic characteristics. The inclusion of additional employer controls changes the sign of the PT penalty into a small premium (of up to 3 log points once all controls have been added). These results are in line with evidence from other (cross-sectional) studies from other countries that find that the “adjusted” PT/FT differential is very small (and it is mainly explained by workers' characteristics and occupational segregation). ${ }^{34}$

Nonetheless OLS estimates are based on a strong assumption that PT status is exogenous (conditional on the included covariates). Clearly this is not the case, as

\footnotetext{
${ }^{33}$ To identify participation into fixed-term versus permanent contract in Spain, Hernanz, 2002, uses gender, age, level of education, industry, public or private employer, firm size and region and working day duration (and occupation on the case of the estimation of the SES sample). De la Rica, 2007, uses age, tenure and education, controls for occupation (at one-digit) and the rate of fixed-term contracts by autonomous community. De la Rica, 2007, does not find evidence of selection into type of contract for females (while there is selection for males). Hernanz's estimates are not presented separately by sex, therefore we are unable to know whether her evidence of selection in the whole sample would hold when the analysis focuses on women.

${ }^{34}$ See, for instance, results from Australia (Rodgers, 2004), Belgium (Jepsen, 2001; Jepsen et al., 2005), Norway (Hardoy and Schøne, 2006), and the UK (Manning and Petrongolo, 2008), among others.
} 
discussed earlier in Section II. To deal with unobserved heterogeneity, we proceed to estimate the following fixed-effects equation (2), with results shown in row 2 of panel A:

$$
L n W_{i t}-\overline{\operatorname{LnW_{i}}}=\left(X_{i t}-\overline{X_{i}}\right) \beta^{\prime}+\theta^{\prime}\left(P T_{i t}-\overline{P T_{i}}\right)+\mu_{i t}-\overline{\mu_{i}}
$$

Notice that the estimator of interest is the coefficient of the indicator variable "parttime” employment, $\theta$. And hence, in the fixed-effects specification, $\theta$ is capturing the switch into part-time employment (regardless of whether the worker changes employer or not). ${ }^{35}$

We find that the fixed-effects estimates display a PT premium in Spain that ranges between 6 and $8.5 \log$ points. Should we infer from these estimates that women working PT in Spain earn higher hourly earnings than those on FT work? Not necessarily. Certainly, these results are difficult to reconcile with the evidence presented earlier (in Section III) suggesting that PT jobs in Spain are in the secondary labor market.

To our knowledge, three other studies have estimated the PT/FT wage differential in Spain using a cross-sectional approach with data from the European Community Household Panel Survey (Pissarides et al., 2005; and Pagán Rodríguez, 2007) and from the 2006 Survey on Income and Living Conditions Vida (Muñoz de Bustillo Llorente et al., 2008). All three studies find evidence of an unadjusted hourly wage penalty associated with being a female PT worker (of between 10\% and 16\%), which becomes a PT premium after adjusting for observable characteristics (and selfselection in the case of Pagán Rodríguez, 2007) in the two studies that use the European

\footnotetext{
${ }^{35}$ This coefficient is estimated with alternative specifications, in which several covariates are sequentially added into the LHS of the equation. In two of these specifications (the second to last and last specifications, shown in columns 6 and 7 of Table 6) we have controlled for whether there has been an employer change in each of the years of the employment history of the individual. Note, however, that in this section of the paper, we do not interact the PT dummy with a change of employer dummy. This is done in Section V.4.
} 
Community Household Panel Survey. ${ }^{36}$ However, the Pissarides et al.'s PT premium vanishes when potential measurement error in hours and PT status are instrumented with lagged values. The authors conclude that they are reluctant to believe their estimates as measurement error may still be affecting their IV estimates. ${ }^{37}$

Given that our data comes from Social Security records it ought to be less spurious than workers' survey data overcoming the measurement error problem found in earlier studies. Nonetheless, given our results thus far, we suspected that our measure of hours, that is, contractual hours, could be consistently underreporting actual worked hours for PT workers relative to FT workers, which would lead to a differential measurement error in contractual hours by PT status. An explanation for this is that employers have an incentive to underreport contractual hours to reduce their labor costs. Given that PT workers tend to be in more vulnerable situations than FT workers (Belous, 1989; Bardasi and Gornich, 2000; Connolly and Gregory 2008 and 2009; Manning and Petrongolo, 2008), and given the higher dispersion of hours worked among PT workers compared to FT workers in Spain (Muñoz de Bustillo Llorente et al., 2008), underreporting of contractual hours, albeit unlawful, seems to be an easier and more common practice for PT contracts than FT ones. Using data from the Time Use Survey, Figure 2 provides evidence that PT workers consistently work a greater number of hours in excess of contractual hours relative to their FT counterparts, which biases upwards the hourly wages of PT workers (relative to FT workers) leading to underestimating the PT wage penalty. ${ }^{38}$

\footnotetext{
${ }^{36}$ In the other study, the 'unadjusted' PT penalty vanishes after controlling for workers' and job characteristics.

${ }^{37}$ The other two studies do not correct for measurement error.

38 The effective-contractual hours' gap for PT workers is significantly different from the gap for FT workers at the $1 \%$ level across all age and education groups.
} 
One way to address this problem is to use imputed effective hours to calculate the hourly wage as opposed to contractual hours. ${ }^{39}$ Rows 3 and 4 of panel A of Table 6 show pooled OLS and fixed-effects estimates using as dependent variable hourly wages calculated with imputed effective hours. The fixed-effects estimates show that, on average, women working PT in Spain earn 19 log points less per hour than their FT counterparts (after controlling for women socio-demographic characteristics-column 2 row 4 of panel A). In addition, comparing rows 3 and 4 of panel A shows that the OLS estimates consistently overestimate the PT penalty relative to the fixed-effect estimates suggesting that women who move into PT are negatively self-selected, a common finding in this literature. These estimates highlight the weaknesses of using crosssectional data for undertaking such type of analysis. A priori, our cross-sectional analysis seemed to offer sound results consistent with those found earlier in the literature. However, the availability of longitudinal data enables us to further investigate our findings and to uncover a new identification problem, not discussed (to our knowledge) in the literature until now.

The analysis thus far has analyzed the average hourly wage difference between women working PT and FT. However, the average effect may hide important differences across groups. In what follows, we study the PT hourly wage penalty by type of contract. The rationale being that the effect of PT on hourly wages and the channels through which it operates may well differ by the level of job protection the worker has, and whether she is in the primary labor market (with a permanent contract) or in the secondary labor market (with a fixed-term contract). For instance, low levels of unionization (Belous, 1989), and lower accumulation of skills and lower returns to skills (Connolly and Gregory, 2009; Manning and Petrongolo, 2008) are found both in

\footnotetext{
${ }^{39}$ Imputed hours come from a regression of worked hours against contractual hours, age, education, twodigit industry dummies and occupation dummies using the Spanish Time Use Survey Dataset.
} 
PT jobs and 'bad' jobs. In addition, Bardasi and Gornich, 2000, have found evidence that this association is likely to be the strongest in countries where the size of the PT labor market is small, that is, where PT work is more likely to be in a 'marginalized' fringe of the labor market, such as in Spain.

Panel B and C of Table 6 replicate the analysis done in panel A but for two separate sub-samples. The heterogeneity analysis shows that the average effect of PT work on hourly wages differs by type of contract, bringing to light that the PT penalty is considerably larger for workers in the secondary labor market. Our preferred estimates (second column of rows 4) show that women with permanent contracts have, on average, 9 log points less hourly earnings than their FT counterparts. However, the PT hourly wage differential more than doubles (23 log points) for women with fixedterm contracts. In addition, examining the results from panels $\mathrm{B}$ and $\mathrm{C}$ shows that the negative sample selection that we are able to correct for when using fixed-effects is considerably larger for workers with permanent contracts. While the PT penalty for workers in the primary sector gets reduced by two thirds when moving from the OLS estimate to the fixed-effects one (from -27 to -9 log points), it only decreases by one third (from -32 to -23 log points) for workers in the secondary labor market. This finding may be explained by the fact that women with permanent contracts have job protection and are 'free' to move to PT work without 'too many' penalties. In contrast, for women with fixed-term contracts their move to PT may be 'less voluntary'. Evidence on voluntariness of PT work shown in Section III corroborates that indeed PT tends to be more involuntary among women with temporary contracts than those with permanent contracts. In addition, we find that the reduction of the differential measurement error bias is greater for women with fixed-term contracts as one would expect if employers are more prone to under-report contractual hours among the most 
vulnerable workers. Finally, Appendix Table A.1 summarizes the fixed-effects coefficients on the control variables for our most complete specification (last column of rows 3 and 4 of Table 6$)$.

While the results in this section highlight the existence of a PT hourly wage differential in Spain, and show that employment protection reduces it by more than half, they cannot provide much guidance on what explains the penalty as some noise remains in the LHS variable due to the fact that its denominator has been imputed (notice that the estimates do not vary much as we control for additional covariates). ${ }^{40}$ In what follows, we propose to analyze how the change in log hourly wages differs by PT status and to explore how working PT affects the workers’ earnings trajectories.

\section{V.2. PT log hourly wage growth differential}

Assuming that differential measurement error by PT status is an individualemployment-status fixed effect, and dropping from our sample the wage observation the year in which the switch from FT to PT occurs, we estimate the effect of working PT on the change in log hourly wages free of differential measurement error. To do so, we estimate the equations (3) (OLS) and (4) (fixed-effects) below:

$$
\Delta L n W_{i t}=X_{i t-1} \beta+\theta P T_{i t-1}+\gamma F I X E D_{i t-1}+\lambda\left(P T_{i t-1} \times F I X E D_{i t-1}\right)+\phi_{i}+\mu_{i t-1}
$$

Here, $\Delta L n W_{i t}$ is the change in the natural log of real hourly earnings of individual $i$ between year $t-1$ and year $t ; X_{i t-1}$ is a vector of individual and job characteristics previously described for individual $i$ at time $t-1$, with $\beta$ the corresponding coefficient vector (including an intercept). $P T_{i t-1}$ is a binary variable equal to one if the worker's principal job is PT in year $t-1 ; F I X E D_{i t-1}$ is a binary variable equal to one if the worker

\footnotetext{
${ }^{40}$ As long as the noise is not related to PT status, it ought not to have an effect on our estimate of PT work.
} 
holds a fixed-term contract at time $t$ - 1 . The error term includes both a random component $\mu_{i t}$ with mean zero and constant variance, and a worker-specific fixed effect $\phi_{i}$. All regressions use the Huber/White estimator of variance and allow for observations not being independent within cluster-individuals.

(4)

$$
\Delta L n W_{i t}-\overline{\Delta L n W_{i}}=\left(X_{i t-1}-\overline{X_{i}}\right) \beta^{\prime}+\theta^{\prime}\left(P T_{i t-1}-\overline{P T_{i}}\right)+\gamma^{\prime}\left(F I X E D_{i t-1}-\overline{F I X E D_{i}}\right)+\lambda^{\prime}\left(\left(P T_{i t-1} \times F I X E D_{i-1}\right)-\left(\overline{P T_{i}} \times \overline{F I X E D_{i}}\right)\right)+\mu_{i t-1}-\overline{\mu_{i}}
$$

As in equation (2), in equation (4) we identify the effect of PT work through those who switch PT status (regardless of whether they change employers or not). In contrast with estimates obtained with equations (1) and (2), in the regressions (3) and (4) we do not use the observation of the year the switch occurs. This implies that we lose those individuals for which we do not observe at least two consecutive periods in a given FT/PT status. If this loss were large, it could lead to a problem of sample selection. Fortunately, the number of individuals that we lose because we do not observe at least two consecutive periods in a given FT/PT status is very small as shown in Table 7 and ought not to be a concern in terms of selection bias as it represents less than $1.3 \%$ of the whole sample, and less than $4 \%$ of those who switch to PT work at some point in the sample-notice also that only half of these we lose to non-employment.

As explained earlier, for ease of exposition, equations (3) and (4) use a simple dummy variable approach to measure the change in log wage differences associated with PT status and type of contract, conditional on controls. ${ }^{41}$

Table 8 presents our pooled OLS and fixed-effects estimates of the PT penalty on wage change using data from the CSWH, and controlling for different covariates.

\footnotetext{
${ }^{41}$ Earnings change function parameters differ between PT and FT status and type of contract, but the gaps in the wage change estimated using the dummy variable approach differ little from those based on separate equations by PT status and contract type, and evaluated at the means.
} 
Panel A shows estimates for the whole sample, whereas Panel B shows the estimates for workers with fixed-term contracts and those with permanent contracts.

There are important differences between women with fixed-term contracts and those with permanent contracts. After accounting for workers' observable and unobservable characteristics (column 3 of Panel B), we find that PT women with permanent contracts experience on average 2.9 log points lower hourly wage growth per year than their FT counterparts, and that PT women with fixed-term contracts experience 3.9 log points lower hourly wage growth per year than their FT counterparts. How large are these estimates? We claim that these estimates are considerably large and concerning. For instance, compared to the effect of education on hourly wage growth, we find that having a college degree or more increases women's hourly wage growth by 2 log points per year compared to women without a high-school degree. Therefore, the size of the PT penalty is almost one-and-a-half that of the college premium among women with permanent contracts and nearly doubles that of the college premium among women with fixed-term contracts. Notice also that the PT penalty for women with fixed-term contracts is one fourth larger (and statistically significantly so) than for women with permanent contracts, suggesting that there is a negative relationship between job protection and the PT penalty.

Also worth highlighting is the change in the estimates when moving from the unadjusted PT growth penalty (column 1 of Panel B) to the penalty once workers' characteristics are accounted for (column 2 of Panel B), especially for women with fixed-term contracts, as the estimate falls more than one fifth, from 3.2 to 2.7 log points. $^{42}$ In addition, we also observe that the PT growth penalty rises to 3.9 log points for women with fixed-term contracts, once we control for unobserved heterogeneity

\footnotetext{
${ }^{42}$ While a decrease is also observed for women with permanent contracts, the size of the decrease is smaller.
} 
(column 3 of panel B), suggesting that there is "second-order" positive selection into PT work for women with fixed-term contracts (remember that the levels estimates showed the traditional "first-order” negative self-selection into PT jobs for women with both types of contracts). ${ }^{43}$

Adding additional controls for employer characteristics, industry, employer and occupation change and intermittences does not change much the results, suggesting that this hourly wage growth FT/PT differential holds even after most of the job characteristics have been controlled for. Our inability to explain the wage growth gap suggests that it does not seem to be explained by the types of jobs women working PT have (compared to those working FT). In Section V.4, we shall explore how changing employers at the time of the switch into PT affects workers' earnings trajectories.

\section{V.3. Sensitivity Analyses}

Before proceeding any further, we discuss the different robustness checks that we have performed and that are shown in the Appendix. First, we have verified the validity of the use of imputed hours by exploring whether a greater measurement error correction takes place among workers older than 34 years old than for those younger than 35 years old as the observed difference between effective and contractual hours (for both PT and FT workers) is greater for the older than the younger workers. Second, we have reestimated our growth analysis with imputed wages to verify that this alternative correction approach delivers the same results as those shown above. Third, we have reestimated our preferred specifications (both in levels and in growth) using an IV approach to control for the endogeneity by type of contract. Fourth, we have reestimated our preferred specifications using employer fixed-effects estimators. Finally,

\footnotetext{
${ }^{43}$ For workers with permanent contracts, we observe the more common negative self-selection result as we move from the OLS estimate to the fixed-effect one.
} 
we re-estimated our preferred specifications for different subgroups to check that the results are not due to omitted variable bias (due to not having non-labor income data) or that they are not driven by women who chose to work PT due to family responsibilities. As is thoroughly explained in the Appendix, overall, the main findings of the paper are robust to all of these sensitivity tests.

\section{V.4. Earnings Trajectories and the cumulative PT penalty}

Up to now, our analysis has focused on the average effect of PT work on hourly wages and wage growth. We have found that there is a PT/FT wage differential both in levels and in growth and that this differential is considerably larger for women with temporary contracts. While we find strong evidence of negative self-selection (especially among women with permanent contracts), there is little support for the explanation that workers', employers' and job’s characteristics reduce the PT/FT wage level and growth gap.

Thus far, we have only controlled for whether the worker changes employer in any given year in two specifications of Tables 6 and $8 .^{44}$ However, we have not analyzed the effect of an employer change at the time of the switch into PT work. In this section we propose to do so, at the same time that we analyze how a switch from FT to PT work affects workers' earnings trajectories, that is, we are interested in knowing whether there is a PT pay penalty not only the first year after switching to PT work but also thereafter. If women in the primary labor market are protected and have certain discretion to reduce work hours, we ought to see that the PT/FT wage gap mainly arises when these women switch employers (and therefore lose their acquired

\footnotetext{
${ }^{44}$ Only the two last specifications (columns 6 and 7 of Table 6, and columns 8 through 11 of Table 8) controlled for whether there had been an employer change in each of the years of the employment history of the individual, however, this change of employer variable was not interacted with the PT dummy.
} 
rights). In contrast, because women in the secondary labor market are in considerably more precarious jobs, it is unclear whether staying with the same employer will preclude them from a reduction in hourly earnings at the time of the PT switch. To proceed in such analysis we estimate the following specifications in levels (equation 5) and in growth (equation 6).

$$
L n W_{i t}-\overline{L n W_{i}}=\left(X_{i t}-\overline{X_{i}}\right) \beta^{\prime}+\theta^{\prime}\left(P T_{i t}-\overline{P T_{i}}\right)+\tau^{\prime}\left(C E_{i t}-\overline{C E_{i}}\right)+\varphi^{\prime}\left(\left(P T_{i t} \times C E_{i t}\right)-\left(\overline{P T_{i t}} \times \overline{C E_{i}}\right)\right)+\mu_{i t}-\overline{\mu_{i}}
$$
Where $C E_{i t}$ is a binary variable equal to one if the worker changed employer the year of the change from FT to PT status. The estimators of interest are the coefficient of the indicator variable "part-time" employment, $\theta$, which captures the switch into PT employment if the worker does not change employer the year of the switch and the sum of the coefficients, $\theta+\tau+\varphi$, which captures the switch into PT employment if the worker changes employer the year of the switch. Notice that this analysis is done separately by type of contract at time $t$.

$$
\begin{aligned}
& \Delta L n W_{i t}-\overline{\Delta L n W_{i}}=\left(X_{i t-1}-\overline{X_{i}}\right) \beta^{\prime}+\sum_{k=1}^{5+} \theta_{k}{ }^{\prime}\left(P T_{i t-k}-\overline{P T_{i}}\right)+\gamma^{\prime}\left(F I X E D_{i t-1}-\overline{F I X E D_{i}}\right)+\sum_{k=1}^{5+} \lambda_{k}{ }^{\prime}\left(\left(P T_{i t-k} \times F I X E D_{i-1}\right)-\left(\overline{P T_{i}} \times \overline{F I X E D_{i}}\right)\right) \\
& +\tau^{\prime}\left(C E_{i t-1}-\overline{C E_{i}}\right)+\sum_{k=1}^{5+} \varphi_{k}{ }^{\prime}\left(\left(P T_{i t-k} \times C E_{i-1}\right)-\left(\overline{P T_{i}} \times \overline{C E_{i}}\right)\right)+\mu_{i t-1}-\overline{\mu_{i}}
\end{aligned}
$$

Where ${ }_{5+}$ is a vector of five dummies indicating whether the individual has been $\sum_{k=1}^{5+} P T_{t-k}$

working PT the last year, for the previous two years, and so on, up to "for the previous five or more”. For a worker who has been working PT the last year, the estimators of interest are: (i) the coefficient of the indicator variable "part-time" employment, $\theta_{1}$, which captures the switch into PT employment if the worker has a permanent contract 
and does not change employer the year of the switch; (ii) the sum of the coefficients, $\theta_{1}+\gamma+\lambda_{1}$, which captures the switch into PT employment if the worker has a fixedterm contract and does not change employer the year of the switch; (iii) the sum of the coefficients, $\theta_{1}+\tau+\varphi_{1}$, which captures the switch into PT employment if the worker has a permanent contract and changes employer the year of the switch; and (4) the sum of the coefficients, $\theta_{1}+\gamma+\lambda_{1}+\tau+\varphi_{1}$, which captures the switch into PT employment if the worker has a fixed-term contract and changes employer the year of the switch.

The coefficients of interest are displayed in Table 9.A. for workers with fixedterm contracts and Table 9.B. for workers with permanent contracts. The coefficient for the year of the switch comes from estimating equation (5) and the other coefficients come from equation (6). These coefficients are plotted in Figure 3, which shows the cumulative PT penalty by type of contract differentiating by whether the worker changes employer at the time of the PT switch or not. While panel A of Figure 3 presents the cumulative PT penalty estimated with the specification that controls for workers' characteristics, panel B shows the estimates when we control for both workers and employers' characteristics.

An important insight emerges from panel A of Figure 3. For workers with permanent contracts, the PT hourly wage gap in levels is mainly explained by the change of employer at the time of the switch to PT work. While no PT penalty is observed among those workers who remain with the same employer, the switch to PT work imposes an immediate earnings penalty of $10 \mathrm{log}$ points if the worker changes employers. $^{45}$ Such differential remains in evidence over at least four years. In addition,

\footnotetext{
${ }^{45}$ These results are in line with those found by Manning and Petrongolo, 2008, for the UK, where they find that for those women who change hours status without changing employer there is a very small pay penalty of $0.2 \%$.
} 
panel B shows that half of this penalty is accounted for by differences in the employers' characteristics of FT and PT workers.

For workers in the secondary labor market, we also find that changing employers at the time of the switch to PT work is a source of earnings penalty of similar size (a bit over 10 log points), of which, one fourth are explained by employers' characteristics. ${ }^{46}$ However, there is a profound difference between workers in the primary and the secondary labor market. Those with temporary contracts suffer an additional hourly wage loss in levels of $9 \log$ points at the time of the switch to PT that is not explained by employer switch or other observable job characteristics.

In addition, Figure 3 also reveals interesting information on the return to PT experience, which is very different in the primary labor market than in the secondary one. For instance, for workers with permanent contracts, the return to PT experience gives a negative return during the first year and becomes flat thereafter. In contrast, for workers in the secondary market (those with fixed-term contract), we find that PT experience gives a negative return for at least the first four years. These results are in line with Hirsch, 2005, and CG who find that accumulated skills account for much of the PT wage disadvantage among workers in the US (the former) and the UK (the latter). Moreover, similar to CG, we find that the returns to PT work are lower in lower level jobs-CG find lower returns to PT work for workers in lower level occupations.

To sum up, for workers in the primary labor market, we find that the PT penalty is explained by the change of employer and lower quality jobs, as well as negligible returns to PT work experience during the first few years in PT work. Once these channels are taken into account, neither PT status nor the switch into PT is associated with a significant pay penalty directly. However, these three channels do give rise to

\footnotetext{
${ }^{46}$ Note that the fact that job characteristics explains less of the PT penalty for workers with fixed-term contracts than for those with permanent contracts is consistent with the fact that jobs in the secondary labor market are already 'bad' jobs.
} 
non-negligible earnings losses, and it takes at least four years for these penalties to vanish. Perhaps not surprisingly, these results are not so different from those found in countries in which PT is well established, such as the UK.

In contrast, for workers in the secondary labor market, the PT penalties are greater and long-lasting, raising serious concern for such workers in these types of contracts. We find that the switch to PT status in itself is associated with a 10 log points immediate drop in earnings that we are unable to explain with workers' observable or unobservable characteristics nor employers' attributes. In addition to this unexplained PT penalty, we find evidence that the returns to experience in PT work are negative. Finally, the PT penalty is exacerbated by lower quality jobs and job change (as it was in the primary labor market).

\section{Direction for Policy}

According to CG, in the UK, there is an excess supply of PT hours by British women. This hypothesis is supported by the fact that there is a high proportion of women in the UK working PT (40\% of the female employment) and that they are happily doing so (80\% of those working PT say they do not wish a FT job), despite the 10.6 log percent loss of hourly earnings this work arrangement represents. In Spain, the issue is drastically different. Spain has one of the lowest proportion of women working PT among advanced economies, and the pay penalty to PT work is among the worst since on average, it almost doubles that of the UK.

The evidence from the UK also indicates that the substantial short- and longterm penalties result from occupational downgrading (Manning and Petrongolo, 2008, and CG). Similarly, in Spain, we find that, in the primary labor market (permanent contracts), the FT/PT wage differential is explained by a change of employer and that 
half of this gap is caused by the different types of jobs these women do. However, the story is considerably more complex in the secondary labor market (temporary contracts). For women with a temporary contract, on top of the $10 \log$ points FT/PT wage gap due to the change of employer, there is an additional $9 \log$ points gap that we are unable to explain with workers' observable or unobservable characteristics, nor employers' attributes. Thus, the FT/PT wage differential, possibly the result of employers' discrimination, a higher cost of hiring or both, is aggravated in the secondary labor market. Not surprisingly, over $60 \%$ of workers (including men and women) working PT in Spain say they would prefer a FT job-compared to no more than one fourth in other European countries.

Regardless of whether the larger PT penalty among temporary workers arises because PT workers are more discriminated against or whether they are more costly to hire than FT workers in the secondary market, it is still a result of this paper that the Spanish dual system of job protection exacerbates the economic cost of PT work. A policy implication from this result is that promoting PT work in order to add flexibility to a rigid labor market, imposes heavy costs to either firms, workers or both unless the difference between permanent and temporary workers is corrected in the first place. Therefore, it is probably best to promote regulation changes that will decrease the high firing costs of workers in the primary segment of the labor market, and that will aim at reducing the differences between fixed-term and permanent workers.

In light of these results it is important to know whether most part-timers in Spain are in that state transitionally, or if they are permanently involved in PT work. ${ }^{47}$ If PT is

\footnotetext{
${ }^{47}$ Much international evidence analyzes the extent to which workers become trapped in particular labor markets and find evidence of strong state persistence. For the US, where the incidence of PT work among prime-aged women is as low as in Spain but temporary contracts are practically inexistent, Blank, 1998, identifies two leading patterns in transitions through PT work. For the majority, a spell in PT work serves as an alternative to FT work, to which they return. The primary role of PT work among American women is thus the "maintenance" one, supporting continued labor maker participations within basically a
} 
mainly a transitional state from FT employment, results from the PT penalty, although concerning, would be equivalent to an idiosyncratic shock in workers' earnings trajectories. In contrast, if we find that women going into PT work remain in that status or alternate it with non-employment, the PT penalty findings ought to raise major social concern. Using similar data than the one used in the current paper, Fernández-Kranz and Rodríguez-Planas, 2010, find that, for women with temporary contracts, PT work in Spain is part of an "exclusionary" cycle, where low-wage, insecure PT jobs alternate with spells of non-employment. While different, the story is not much more promising for women with permanent contracts. Fernández-Kranz and Rodríguez-Planas, 2010, find that while continuing FT work is by far the most prevalent state in the primary labor market, when women work PT, their work arrangements follow the same “exclusionary” pattern than in the secondary market. These authors' findings suggest that,- - except for a minority of women with permanent contracts who do not change employers for whom PT spells have a role as "maintenance" spells supporting continued labor market participation within a basically FT career-, PT jobs in Spain are a dead-end for Spanish women's careers. All in all, it ought not to come to a surprise that Spanish women do not want to work PT, especially if they are in the secondary labor market.

Finally, our results bring to light another dimension of gender and family pay gaps in segmented labor markets. Given the relative concentration of mothers in PT

FT career. The other major group, which Blank identifies enter PT work from non-employment and then leave the labor market again, showing PT work forming part of an "exclusionary" cycle of weak labor market attachment. Using data on the UK, where PT work among prime-aged women is considerably more common than in Spain but fixed-term contracts are not as frequently used, O'Reilly and Bothfeld, 2002; and Connolly and Gregory, 2010, find diverging results. While O’Reilly and Bothfeld find that over a five-year period, PT work follows an "exclusionary” pattern where it is interspersed with spells of non-employment; Connolly and Gregory, 2010, follow a 1958 birth cohort from their early twenties until they are aged 42 in 2000 and find that PT work serves two different functions. Women whose past history predominantly involves FT work, possibly in conjunction with spells of PT work or nonemployment, revert to FT work. Women whose labor market histories combine spells in PT with nonemployment are unlikely to subsequently take up FT work. According to these authors, PT work is both a support and a trap for women's future careers, but these alternative roles apply to different groups. 
work, they suggests that Spain is still far from enabling the conciliation of work and family through the reduction of regular work schedule. While PT work seems to be an option for reconciling work and family for some women with permanent contracts, this is clearly not the case for women with fixed-term contracts (Fernández-Kranz and Rodríguez-Planas, 2010). Given the vast reserve of potential labor force that represent inactive women in Spain, ${ }^{48}$ and considering the challenges that the Spanish society has in reconciling work and family, ${ }^{49}$ the current laws allowing for flexible working hours for mothers of young children are clearly not sufficient. Other policies (such as raising the availability of affordable good-quality childcare) ought to be used to help women turn to FT jobs with more prospects. An alternative solution may be to reduce the negative future career consequences of a period spent in PT work, for example by giving parents greater rights to change hours (including to work PT but also to resume their full-time job). While the right to request flexible work arrangements was first introduced in Spain in 1999 by giving parents of children under eight or with dependents the right to work flexibly, the impact to date appears to have been limited to workers in the primary labor market who do not change employers, as those with fixedterm contracts are let go when their contract expires (Fernandez-Kranz and RodríguezPlanas, 2010).

\footnotetext{
${ }^{48}$ Buddelmeyer et al. (2005) estimate that 38\% of females remained inactive in Spain between 1994 and 1999 (compared to an average of $26 \%$ in the EU).

${ }^{49}$ Sanchez-Mangas and Sanchez-Marcos (2008) highlight the following five stylized facts that illustrate the difficulties Spanish mothers have in reconciling employment and family. First, the Spanish employment rate for mothers is among the lowest in the OECD (Gutiérrez-Domenech, 2005). Second, Spanish maternity leave is, on average, nine weeks shorter than in most of the European countries (OECD, 2001). Third, the use of formal child-care arrangements for three-year-old children is much less frequent in Spain than in the average European country. For instance, in 2001 the proportion of children under the age of three in preschool was only 9 percent in Spain, in sharp contrast with the European average of 25 percent. Fourth, the 2004 Spanish Labor Population Survey indicates that 29 percent of women aged 45 and younger reported family responsibilities as their main reason for not participating in the labor market. Last, but not least, having one of the lowest fertility rate among the EU-15 countries is also indicative of difficulties of reconciling work and family in Spain (Eurostat, 2007).
} 


\section{REFERENCES}

Aaronson, D., and E. French. 2004. "The Effect of Part-Time Work on Wages: Evidence from the Social Security Rules.” Journal of Labor Economics, Vol. 22, No. 2 (April): 329-352.

Adam, P., 1996. “Mothers in an Insider-Outsider Economy: the Puzzle of Spain.” Journal of Population Economics 9, 301- 323.

Altonji, J. 1986. "Intertemporal Substitution in Labor Supply: Evidence from Microdata." Journal of Political Economy 94 (June): S176-S215.

Amuedo-Dorantes, C. 2000. "Work Transitions Into and Out of Involuntary Employment in a Segmented Market: Evidence from Spain,” Industrial Labor Relations Review, 2000, 53(2): 309-325.

Argimón, I., and C. González. 2006. "La Muestra Continua de Vidas Laborales de la Seguridad Social.” Boletín Económico, Banco de España, (May): 39-53.

Barceló C. and E. Villanueva, 2010. "The response of household wealth to the risk of losing the job: evidence from differences in firing costs.” Banco de España Working Paper no. 1002

Bardasi E., and J. C. Gornick. 2000. "Women and Part-Time Employment: Workers' Choices and Wage Penalties in Fve Industrialized Countries." Institute for Social and Economic Research, ISER Discussion Paper, No. 11.

Belous R. 1989. “The Contingent Employment: The Growth of Temporary, Part-Time, and Subcontracted Workforce.” Washington D.C.: Nacional Planning Association.

Beninger. D. 2005. “Emploi et social en France: Description et evaluation.” ZEW Documentation 03-05, Mannheim, ZEW.

Bentolila, S. and J. Dolado. 1994. "Labour Flexibility and Wages: Lessons from Spain.” Economic Policy 18: 53-99.

Bentolila S. J. J. Dolado, and J.F. Jimeno. 2008. “Two-Tier Employment Protection Reforms: The Spanish Experience.” CESifo DICE Report 4/2008.

Blanchard O. and A. Landier. 2002. "The Perverse Effects of Partial Labor Market Reform: Fixed Duration Contracts in France.” NBER Working Paper 8219, Cambridge, NBER.

Blank, R. 1990. “Are Part-Time Jobs Lousy Jobs?” In A Future of Lousy Jobs? edited by Gary Burtless, pp. 123-155. Washington, DC: The Brookings Institute.

Blank, R. 1998. "Labor Market Dynamics and Part-Time Work", in Solomon W. Polacheck (ed.), Research in Labor Economics, Volume 17, JAI Press, Stamford, Connecticut.

Bentolila S., and G. Saint Paul. 1992. "The Macroeconomic Impact of Flexible Labor Contracts, with an Application to Spain.(with Gilles Saint-Paul).” European Economic Review 36, 1992.

Booth and van Ours. 2008. "Job Satisfaction and Family Happiness: The Part-time Work Puzzle.” Economic Journal 118(526): F77-F99. 
Booth A., and M. Woods. 2008. "Back-to-Front Down Under? Part-Time/ Full-Time Wage Differentials in Australia." Industrial Relations, Vol. 47, No. 1.

Bound, John, C. Brown, and N. Mathiowetz. 2001. "Measurement Error in Survey Data.” In Handbook of econometrics, vol. 5, ed. James Heckman and Ed Leamer, 3705-3843. Amsterdam: North-Holland.

Bover, O., and R. Gómez. 2004. "Another Look at Unemployment Duration: Exit to a Permanent Job vs. a Temporary Job,” Investigaciones Economicas, 28(2): 285314.

Buddelmeyer H., G. Mourre, and M. Ward-Warmedinger. 2005. "Part-Time Work in EU Countries. Labour Market Mobility, Entry and Exit.” European Central Bank Working Paper n. 460.

Buligescu, B., de Crombrugghe, D., Mentesoglu, G., and Montizaan, R. 2009. "Panel Estimates of the Wage Penalty for Maternal Leave.” Oxford Economic Papers, 61: 35-55.

Cahuc P. and F. Kramarz. 2004. "De la Précarité à la Mobilité: Vers une Sécurité Sociale Professionnelle.” Rapport au Ministre d'Etat, Ministre de l'Economie, des Finances et de l’Industrie et au Ministre de l’Emploi, du Travail et de la Cohésion Sociale, Paris.

Clark, A.E., and C. Senik. 2006. "The (Unexpected) Structure of 'Rents' in the French and British Labour Markets.” Journal of Socio-Economics 35(2): 180-96.

Connolly, S. and M. Gregory. 2008. "Moving Down: Women’s Part-Time Work and Occupational Change in Britain, 1991-2001.” Economic Journal, vol. 118: F52-F76.

Connolly, S. and M. Gregory. 2009. "The Part-Time Pay Penalty: Earnings Trajectories of British Women.” Oxford Economic Papers, vol. 61 no. S1 : 76-97.

Connolly, S. and M. Gregory. 2010. "Dual Tracks: Part-Time Work in Life-Cycle Employment for British Women.” Journal of Population Economics.

De la Rica, S. 2004. "Wage Gaps between Workers with Indefinite and Fixed-Term Contracts: The Impact of Firm and Occupational Segregation." Moneda y Crédito 219: 43-69.

Dolado, J. J., F. Felgueroso, F., and J.F. Jimeno. 1999. "Los problemas del mercado de trabajo juvenil en España: empleo, formación y salarios mínimos.” Ekonomiaz, vol. 43, pp. 13657.

Dolado, J., C. García-Serrano and J.F. Jimeno. 2002. "Drawing Lessons from the Boom of Temporary Jobs in Spain,” Economic Journal, 112(480): F270-295.

Dolado, J.; M. Jansen, and J.F. Jimeno. 2007. "A Positive Analysis of Targeted Employment Protection Legislation," The B.E. Journal of Macroeconomics: Vol. 7 : Iss. 1 (Topics), Article 14.

Employee Benefits Research Institute. 1993. "Part-Time Work: Characteristics of the PartTime Work Force: Analysis of the March 1992 Current Population Survey.” Working Paper P-55.

Eichhorst, W. 2007. "The Gradual Transformation of Continental European Labor Markets: France and Germany Compared.” IZA Discussion Paper 2675. 
Ermisch, J., and R. Wright. 1993. "Wage offers and full-time and part-time employment by British women.” Journal of Human Resources, vol 28 (Winter), 111-33.

Ferber M., and J. Waldfogel, 1998. "The Long-Term Consequences of Non-Standard Work", Monthly Labor Review, Vol. 121: 3 - 12.

Fernández-Kranz, D., and A. Lacuesta. 2009. “Mothers’ Quest for Job Protection: Building the Nest or Breaking the Glass Ceiling? Evidence Using Spanish Longitudinal Data.” IE Business School Working Paper.

Fernandez Kranz D., and N. Rodríguez-Planas. 2010. "Is Part-Time a Dead-End Job, a Stepping-Stone, o a Tool for Reconciling Work and Family? Evidence from a Segmented Labor Market”.

Gallie D., M. White, Y. Cheng and M. Tomlinson. 1998. "Restructuring the Employment Relationship.” Oxford University Press, 1998.

García-Ferreira M. and E. Villanueva, 2007. "Employment Risk and Household Formation: Evidence from firing costs.” Working Paper no 737, Banco de España.

García-Pérez, J. I. and Y. Rebollo-Sanz, 2009. "The Use of Permanent Contracts Across Spanish Regions: Do RegionalWage SubsidiesWork?” Investigaciones Económicas, 33, pp. 39-68.

Gornick, J., and J. Jacobs. 1996. "A Cross-National Analysis of The Wages of Part-Time Workers: Evidence from the United States, the United Kingdom, Canada, and Australia." Work, Employment and Society, 10/1: 1-27.

Gregory, M., and S. Connolly. 2008. "The Price of Reconciliation: Part-time Work, Families and Women’s Satisfaction.” Economic Journal, Vol. 118 (february), pp. F1-F7.

Galdón-Sánchez, and M. Güell. 2003. “Dismissal Conflicts and Unemployment.” European Economic Review, 47 (2): 127-139.

Güell, M. and B. Petrongolo. 2007. "How Binding are Legal Limits?: Transitions from Temporary to Permanent Work in Spain”, Labour Economics 14, 153-183.

Gutiérrez-Doménech M. 2005. “Employment Transitions After Motherhood in Spain”, Labour Special Issue, 19(0), 123-148.

Hakim, C. 1997. “A Sociological Perspective on Part-Time Work,” in Hans-Peter Blossfeld, and Catherine Hakim (eds.), In Between Equalization and Marginalization:Women Working Part-Time in Europe and The United States of America. Oxford: Oxford University Press, 22-70.

Hardoy I. and P. Schøne, 2004. “The Part-Time Wage Gap: How Large Is it Really?” British Journal of Industrial Relations 44:2 June 2006, pp. 263-282.

Hernanz, V. 2002. "El Trabajo Temporal y la Segmentación: Un Estudio de las Transiciones Laborales.” Unpublished PhD Dissertation, Universidad de Alcalá de Henares, Madrid.

Hirsch, B. 2005. "Why Do Part-Time Workers Earn Less? The Role of Worker and Job Skills.” Industrial and Labor Relations Review 58(July):525-51. 
Hotchkiss, J. 1991. “The Definition of Part-Time Employment: A Switching Regression Model with Unknown Sample Selection.” International Economic Review, Vol. 32, No. 4 (November): 899-917.

Hu, Y. and K. Tijdens, K. 2003. "Choices for Part-Time Jobs and the Impacts on the Wage Differentials. A Comparative Study for Great Britain and the Netherlands”, An Integrated Research Infrastructure in the Socio-Economic Sciences at CEPS/INSTEAD, IRISS Working Paper, No. 2003-05, 36p.

Jepsen M., 2001. "Some Evidence on the Price for Working Part-Time", $\mathrm{PhD}$ in Economics,Université Libre de Bruxelles.

Jepsen, M., O’Dorchai, S., Plasman, R. and Rycx, F. 2005. “The Wage Penalty Induced by Part-Time Work: The Case of Belgium”, Brussels Economic Review, Vol. 48, No. 1/2, pp. 73-94.

Jimeno, J.F. and L. Toharia. 1993. "The Effects of Fixed-Term Employment on Wages: Theory and Evidence from Spain,” Investigaciones Económicas, 17(3): 475-494.

Jimeno, J. F., and L. Toharia. 1996. "Effort absenteeism, and fixed-term employment contracts.” Revista Española de Economía, vol. 13(1), pp. 105-19.

Jimeno, J.F., and A.C. Ortega. 2003. "Veinticinco Años de Mercado de Trabajo en España.” Economía Industrial, num. 349-350.

Jones, E., and J. Long. 1979. "Part-Week Work and Human Capital Investment by Married Women.” Journal of Human Resources, vol. 14 (Autumn), pp. 563-78.

Izquierdo, M., and Lacuesta, A. 2007. "Wage Inequality in Spain: Recent Developments." Banco de España Research Paper No. 0615; ECB Working Paper No. 781.

Kugler A., J.F. Jimeno, V. Hernanz. 2005. "Employment Consequences of Restrictive Permanent Contracts: Evidence from Spanish Labor Market Reforms.”, IZA working papers 657.

López Bóo F., L. Madrigal, and C. Pagés. 2009. "Part-Time Work, Gender and Job Satisfaction: Evidence from a Developing Country.” Inter-American Development Bank, research department working paper.

Manning, A. and B. Petrongolo. 2008. “The Part-Time Pay Penalty for Women in Britain.” The Economic Journal, 118: F28-51.

Mocan, H. N., and E. Tekin. 2003. "Nonprofit Sector and Part-Time Work: An Analysis of Employer-Employee Matched Data of Child Care Workers." Review of Economics and Statistics, Vol. 85, No. 1 (February): pp. 38-50.

Mumford, K. and P. Smith. 2007. "The Gender Earnings Gap in Britain: Including the Workplace.” Manchester School, 75: 653-72.

Muñoz de Bustillo Llorente R., E. Fernández Macías, and J.I. Antón Pérez. 2008. “El Trabajo a Tiempo Parcial en España en el Contexto de la Unión Europea.” Ministerio de Trabajo e Immigración. Colección Informes y Estudies, Serie Empleo, n. 36.

OECD. 2002. “Women at Work: Who Are They and How Are They Faring?” Employment Outlook, 63-125. 
O’Connell P., and V. Gash. 2003. “The Effects of Working Time, Segmentation and Labour Market Mobility on Wages and Pensions in Ireland.” British Journal of Industrial Relations, 41:1 (March): 71-95.

O’Dorchai, S., R. Plasman, and F. Rycx. 2007. “The Part-Time Wage Penalty in European Countries: How Large Is It for Men?” IZA Discusión Paper, 2591.

O’Reilly J. and Bothfeld, S. 2002.”What Happens after Working Part-Time? Integration, Maintenance, or Exclusionary Transitions in Britain and Western Germany.” Cambridge Journal of Economics, vol. 26, 4, pp. 409-39.

Pagán Rodríguez R. 2007. "Diferencias Salariales entre el Empleo a Tiempo Completo y el Parcial.” Revista de Economia Aplicada, vol. XV, 43.

Pissarides, C., P. Garibaldi, C. Olivetti, B. Petrongolo, and E. Wasmer. 2005. "Women in the labor force: how well is Europe doing?” In: Boeri, Tito and Del Boca, Daniela and Pissarides, Christopher, (eds.) Women at work: an economic perspective. Oxford University Press, Oxford, UK, pp. 9-120. ISBN 0199281882

Rodgers, J. 2004. "Hourly Wages of Full-Time and Part-Time Employees in Australia." Australian Journal of Labour Economics 7(June):231-54.

Sánchez-Mangas, R. and Sánchez-Marcos, V. 2008. "Balancing Family and Work: the Effect of Cash Benefits for Working Mothers”, Labour Economics, 15 (6), 1127-1142.

Segura, J. F. Durán, L. Toharia and S. Bentolila. 1991. “Análisis de la Contratación Temporal en Espanta.” Centro de Publicaciones, Ministerio de Trabajo y Seguridad Social

Simpson, W. 1986. “Analysis of Part-Time Pay in Canada.” Canadian Journal of Economics 19(November):798-807.

Van Praag, B.M.S., and A. Ferrer-i-Carbonell. 2004. Happiness Quantified. Oxford, United Kingdom: Oxford University Press.

Wolf, E. 2002. "Lower Wage Rates for Fewer Hours? A Simultaneous Wage-Hours Model for Germany.” Labour Economics, 9: 643-63. 
Table 1

Incidence of Female Part-Time and Fixed-Term Employment, OECD 2008

\begin{tabular}{|l|c|c|}
\hline & $\begin{array}{c}\text { Incidence of female PT } \\
\text { employment }\end{array}$ & $\begin{array}{c}\text { Incidence of female } \\
\text { temporary employment }\end{array}$ \\
\hline Australia & $37.7 \%$ & $5.9 \%$ \\
\hline Belgium & $33.8 \%$ & $9.7 \%$ \\
\hline Germany & $38.6 \%$ & $14.9 \%$ \\
\hline The Netherlands & $59.9 \%$ & $20 \%$ \\
\hline Norway & $30.8 \%$ & $11.1 \%$ \\
\hline Spain & $\mathbf{2 1 . 1 \%}$ & $\mathbf{3 1 . 2 \%}$ \\
\hline The United Kingdom & $37.7 \%$ & $6 \%$ \\
\hline The United States & $17.8 \%$ & $4.2 \%$ \\
\hline
\end{tabular}

Table 2

Part-Time Employment and Type of Contract by Type of Contract in Spain Workers 20 to 65 years old 1999-2009 Labor Force Survey $\left(2^{\text {nd }}\right.$ Semester)

\begin{tabular}{|l|c|c|}
\hline & Permanent contract & Temporary contract \\
\hline & \multicolumn{2}{|c|}{ Women } \\
\hline \% Working PT & $15.67 \%$ & $29.84 \%$ \\
\hline \% Working FT & $84.33 \%$ & $70.16 \%$ \\
\hline Sample size & 161,155 & 78.073 \\
\hline & \multicolumn{2}{|c|}{ Men } \\
\hline \% Working PT & $1.45 \%$ & $6.77 \%$ \\
\hline \% Working FT & $98.55 \%$ & $93.23 \%$ \\
\hline Sample size & 240,234 & 92,920 \\
\hline
\end{tabular}

Figure 1

Full-time Job Preferences

2005 Social Survey Programme (ISSP)—Work Orientations Module

Panel A.

$\%$ that Would Prefer a Full-Time Job (working full-time)

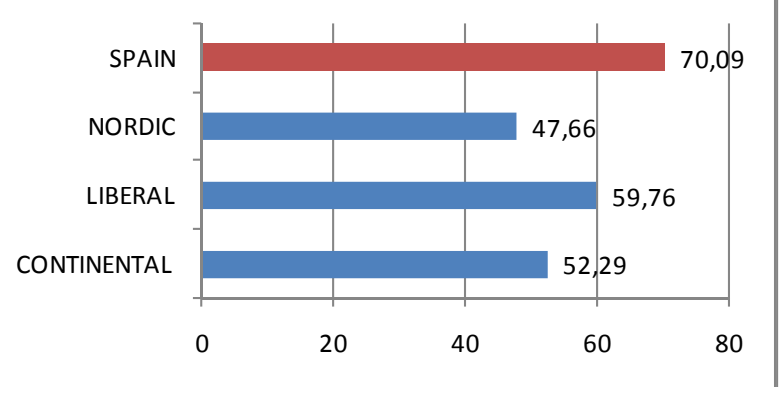

Panel B.

\% that Would Prefer a Full-Time Job (working part-time)

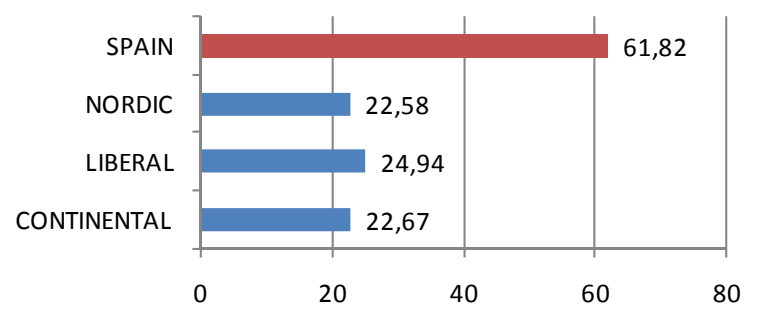




\section{Table 3}

Reasons for Working Part-Time Employment by Type of Contract and Sex in Spain

Workers 20 to 65 years old

1999-2009 Labor Force Survey ( $2^{\text {nd }}$ Semester)

\begin{tabular}{|c|c|c|}
\hline & Permanent contract & Temporary contract \\
\hline & \multicolumn{2}{|c|}{ Women } \\
\hline \multicolumn{3}{|c|}{ Involuntary PT work } \\
\hline Could not find a FT job & $24.99 \%$ & $40.46 \%$ \\
\hline $\begin{array}{l}\text { PT work was a job } \\
\text { requirement }\end{array}$ & $22.94 \%$ & $24.65 \%$ \\
\hline \multicolumn{3}{|c|}{ Voluntary PT work } \\
\hline Family reasons & $28.60 \%$ & $12.48 \%$ \\
\hline Educational or health reasons & $18.02 \%$ & $16.03 \%$ \\
\hline \multicolumn{3}{|l|}{ 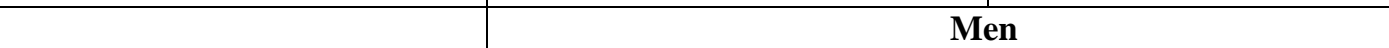 } \\
\hline \multicolumn{3}{|c|}{ Involuntary PT work } \\
\hline Could not find a FT job & $24.62 \%$ & $38.31 \%$ \\
\hline $\begin{array}{l}\text { PT work was a job } \\
\text { requirement }\end{array}$ & $34.64 \%$ & $24.68 \%$ \\
\hline \multicolumn{3}{|c|}{ Voluntary PT work } \\
\hline Family reasons & $4.47 \%$ & $0.97 \%$ \\
\hline Educational or health reasons & $27.51 \%$ & $28.20 \%$ \\
\hline
\end{tabular}

Table 4

Sample Sizes

Women Strongly Attached to the Labor Force, 1996-2006 CSWH

(24 to 45 years old)

(In parenthesis, as a \% of the total number of individuals in each category)

\begin{tabular}{|c|c|c|c|}
\hline & Whole sample & $\begin{array}{c}\text { Permanent contract at } \\
\text { time } t-1\end{array}$ & $\begin{array}{c}\text { Fixed-term contract at } \\
\text { time } t-1\end{array}$ \\
\hline Number of individuals & 76,025 & 54,726 & 50,015 \\
\hline Of which only work FT & $59,556 \quad(78.34 \%)$ & $44,504 \quad(81.13 \%)$ & $35,947 \quad(71.87 \%)$ \\
\hline Of which switch to PT & $(21.66 \%)$ & $(18.68 \%)$ & $(28.13 \%)$ \\
\hline Of which return to FT & $8,153 \quad(49.51 \%)$ & $4,968 \quad(48.60 \%)$ & $7,549 \quad(53.34 \%)$ \\
\hline
\end{tabular}

Note: Because one individual can appear under different categories in different waves of the panel, the number on individuals who were on a permanent contract plus those on a fixed contract is larger than the whole sample. 
Table 5. Descriptive Statistics. Women Strongly Attached to the Labor Force, 2006 CSWH

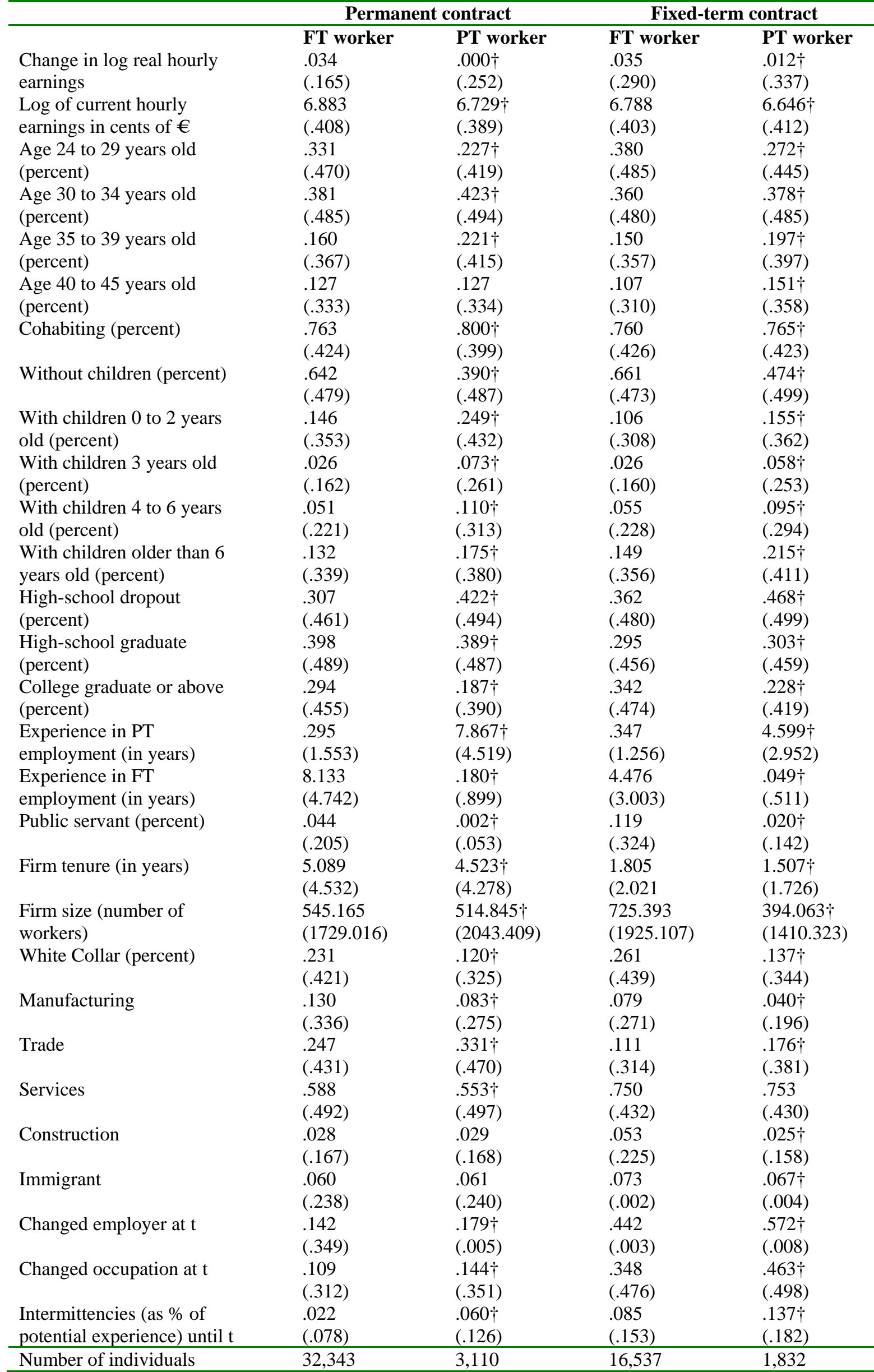

Note.- The numbers in parenthesis are standard deviations. All hourly wages are deflated by the gross domestic product $($ GDP) deflator (base year $=2006)$. † PT mean significantly different from FT mean at the $90 \%$ confidence level. 
Table 6

Estimation of the Part-Time Pay Penalty, Different methodologies

Dependent variable: Ln(real hourly wage)

\begin{tabular}{|c|c|c|c|c|c|c|c|}
\hline & Unadjusted & $\begin{array}{l}+ \\
\text { Workers } \\
\text { controls }\end{array}$ & $\begin{array}{l}+ \\
\text { Employer } \\
\text { characteristic }\end{array}$ & $\begin{array}{l}+ \\
\text { Industry } \\
\text { controls }\end{array}$ & $\begin{array}{l}+ \\
\text { Occupation } \\
\text { controls }\end{array}$ & $\begin{array}{l}+ \\
\text { Change } \\
\text { occupation } \\
\text { or } \\
\text { employer }\end{array}$ & $\begin{array}{l}+ \\
\text { Intermitte } \\
\text { nces }\end{array}$ \\
\hline \multicolumn{8}{|c|}{ Panel A: Whole sample (number of observations : 591,063) } \\
\hline $\begin{array}{l}\text { 1. Pooled } \\
\text { OLS }\end{array}$ & $\begin{array}{c}-.109 * * * \\
(.003)\end{array}$ & $\begin{array}{c}-.033 * * * \\
(.003)\end{array}$ & $\begin{array}{c}-.025^{* * *} \\
(.003)\end{array}$ & $\begin{array}{c}+.005^{*} \\
(.003)\end{array}$ & $\begin{array}{c}+.027 * * * \\
(.002)\end{array}$ & $\begin{array}{c}+.028 * * * \\
(.002)\end{array}$ & $\begin{array}{c}+.029 * * * \\
(.002)\end{array}$ \\
\hline $\begin{array}{l}\text { 2. Fixed- } \\
\text { effects }\end{array}$ & $\begin{array}{c}+.062 * * * \\
(.001)\end{array}$ & $\begin{array}{c}+.070 * * * \\
(.001)\end{array}$ & $\begin{array}{c}+.075^{* * *} \\
(.001)\end{array}$ & $\begin{array}{c}+.079 * * * \\
(.001)\end{array}$ & $\begin{array}{c}+.085 * * * \\
(.001)\end{array}$ & $\begin{array}{c}+.085 * * * \\
(.001)\end{array}$ & $\begin{array}{c}+.085 * * * \\
(.001)\end{array}$ \\
\hline \multicolumn{8}{|c|}{ Using imputed effective hours to estimate LHS variable } \\
\hline $\begin{array}{l}\text { 3. Pooled } \\
\text { OLS }\end{array}$ & $\begin{array}{c}-.376^{* * *} \\
(.003)\end{array}$ & $\begin{array}{c}-.298 * * * \\
(.003)\end{array}$ & $\begin{array}{c}-.290 * * * \\
(.003)\end{array}$ & $\begin{array}{c}-.259 * * * \\
(.003)\end{array}$ & $\begin{array}{c}-.236 * * * \\
(.003)\end{array}$ & $\begin{array}{c}-.234 * * * \\
(.003)\end{array}$ & $\begin{array}{c}-.232 * * * \\
(.003)\end{array}$ \\
\hline $\begin{array}{l}\text { 4. Fixed- } \\
\text { effects }\end{array}$ & $\begin{array}{c}-.195 * * * \\
(.001)\end{array}$ & $\begin{array}{c}-.187 * * * \\
(.001)\end{array}$ & $\begin{array}{c}-.182^{* * *} \\
(.001)\end{array}$ & $\begin{array}{c}-.176^{* * *} \\
(.001)\end{array}$ & $\begin{array}{c}-.171 * * * \\
(.001)\end{array}$ & $\begin{array}{c}-.171 * * * \\
(.001)\end{array}$ & $\begin{array}{c}-.171^{* * *} \\
(.001)\end{array}$ \\
\hline \multicolumn{8}{|c|}{ Panel B: With fixed-term contracts (number of observations: 194,218 ) } \\
\hline $\begin{array}{l}\text { 1. Pooled } \\
\text { OLS }\end{array}$ & $\begin{array}{c}-.057 * * * \\
(.004)\end{array}$ & $\begin{array}{c}-.023 * * * \\
(.004)\end{array}$ & $\begin{array}{l}-.005 \\
(.004)\end{array}$ & $\begin{array}{c}+.016 * * * \\
(.003)\end{array}$ & $\begin{array}{c}+.031 * * * \\
(.003)\end{array}$ & $\begin{array}{c}+.032 * * * \\
(.003)\end{array}$ & $\begin{array}{c}+.031^{* * *} \\
(.003)\end{array}$ \\
\hline $\begin{array}{l}\text { 2. Fixed- } \\
\text { effects }\end{array}$ & $\begin{array}{c}+.049 * * * \\
(.002)\end{array}$ & $\begin{array}{c}+.055^{* * *} \\
(.002)\end{array}$ & $\begin{array}{c}+.062 * * * \\
(.002)\end{array}$ & $\begin{array}{c}+.068 * * * \\
(.002)\end{array}$ & $\begin{array}{c}+.069 * * * \\
(.002)\end{array}$ & $\begin{array}{c}+.070 * * * \\
(.002)\end{array}$ & $\begin{array}{c}+.071^{* * *} \\
(.002)\end{array}$ \\
\hline \multicolumn{8}{|c|}{ Using imputed effective hours to estimate LHS variable } \\
\hline $\begin{array}{l}\text { 3. Pooled } \\
\text { OLS }\end{array}$ & $\begin{array}{c}-.352 * * * \\
(.004)\end{array}$ & $\begin{array}{c}-.319 * * * \\
(.004)\end{array}$ & $\begin{array}{c}-.300^{* * *} \\
(.004)\end{array}$ & $\begin{array}{c}-.277 * * * \\
(.004)\end{array}$ & $\begin{array}{c}-.262 * * * \\
(.004)\end{array}$ & $\begin{array}{c}-.261 * * * \\
(.004)\end{array}$ & $\begin{array}{c}-.260 * * * \\
(.004)\end{array}$ \\
\hline $\begin{array}{l}\text { 4. Fixed- } \\
\text { effects }\end{array}$ & $\begin{array}{c}-.237 * * * \\
(.003)\end{array}$ & $\begin{array}{c}-.230 * * * \\
(.003)\end{array}$ & $\begin{array}{c}-.223 * * * \\
(.003)\end{array}$ & $\begin{array}{c}-.216 * * * \\
(.003)\end{array}$ & $\begin{array}{c}-.215^{* * *} \\
(.003)\end{array}$ & $\begin{array}{c}-.213^{* * * *} \\
(.003)\end{array}$ & $\begin{array}{c}-.213^{* * * *} \\
(.003)\end{array}$ \\
\hline \multicolumn{8}{|c|}{ Panel C: With permanent contracts (number of observations: 396,845 ) } \\
\hline $\begin{array}{l}\text { 1. Pooled } \\
\text { OLS }\end{array}$ & $\begin{array}{c}-.122 * * * \\
(.005)\end{array}$ & $\begin{array}{c}-.037 * * * \\
(.004)\end{array}$ & $\begin{array}{c}-.033 * * * \\
(.004)\end{array}$ & $\begin{array}{l}+.005 \\
(.004)\end{array}$ & $\begin{array}{c}+.034 * * * \\
(.004)\end{array}$ & $\begin{array}{c}+.036 * * * \\
(.004)\end{array}$ & $\begin{array}{c}+.040 * * * \\
(.004)\end{array}$ \\
\hline $\begin{array}{l}\text { 2. Fixed- } \\
\text { effects }\end{array}$ & $\begin{array}{c}+.111 * * * \\
(.002)\end{array}$ & $\begin{array}{c}+.119 * * * \\
(.002)\end{array}$ & $\begin{array}{c}+.120 * * * \\
(.002)\end{array}$ & $\begin{array}{c}+.121 * * * \\
(.002)\end{array}$ & $\begin{array}{c}+.127 * * * \\
(.002)\end{array}$ & $\begin{array}{c}+.128 * * * \\
(.002)\end{array}$ & $\begin{array}{c}+.128 * * * \\
(.002)\end{array}$ \\
\hline \multicolumn{8}{|c|}{ Using imputed effective hours to estimate LHS variable } \\
\hline $\begin{array}{l}\text { 3. Pooled } \\
\text { OLS }\end{array}$ & $\begin{array}{c}-.360 * * * \\
(.005)\end{array}$ & $\begin{array}{c}-.273 * * * \\
(.005)\end{array}$ & $\begin{array}{c}-.269 * * * \\
(.005)\end{array}$ & $\begin{array}{c}-.229 * * * \\
(.004)\end{array}$ & $\begin{array}{c}-.200 * * * \\
(.004)\end{array}$ & $\begin{array}{c}-.197 * * * \\
(.004)\end{array}$ & $\begin{array}{c}-.191 * * * \\
(.004)\end{array}$ \\
\hline $\begin{array}{l}\text { 4. Fixed- } \\
\text { effects }\end{array}$ & $\begin{array}{c}-.095 * * * \\
(.003)\end{array}$ & $\begin{array}{c}-.087 * * * \\
(.003)\end{array}$ & $\begin{array}{c}-.086^{* * *} \\
(.003)\end{array}$ & $\begin{array}{c}-.085 * * * \\
(.003)\end{array}$ & $\begin{array}{c}-.079 * * * \\
(.002)\end{array}$ & $\begin{array}{c}-.077 * * * \\
(.002)\end{array}$ & $\begin{array}{c}-.078^{* * * *} \\
(.002)\end{array}$ \\
\hline
\end{tabular}

*** Significant at $1 \%$ level. Imputed hours come from a regression of effectively worked hours against contractual hours, age, ducation, two-digit industry and occupation using the Spanish Time Use Survey Dataset. A negative number indicates a penalty for partme workers. Each set of regressions has the following controls: UNADJUSTED - year and province dummies; WORKERS CONTROLS age, education, nationality, province of residence, experience and quadratic of experience, tenure, dummies that indicate the presence in e household of children and of children less than 6 years old, and a dummy indicator for immigrant status; EMPLOYER HARACTERISTICS - number of workers, public sector dummy; INDUSTRY \& OCCUPATION - two-digits industry dummies and ten ccupation categories dummies; CHANGE OF EMPLOYER - a dummy indicating if the individual's employer at year t is different from tINTERMITTENCIES - the number of years not working relative to the number of years of potential experience. Potential experience is lculated as the difference between the current year and the year of entry in the Social Security System. 
Figure 2

Contractual and Effective Hours for PT and FT Workers

2003 Time Use Survey

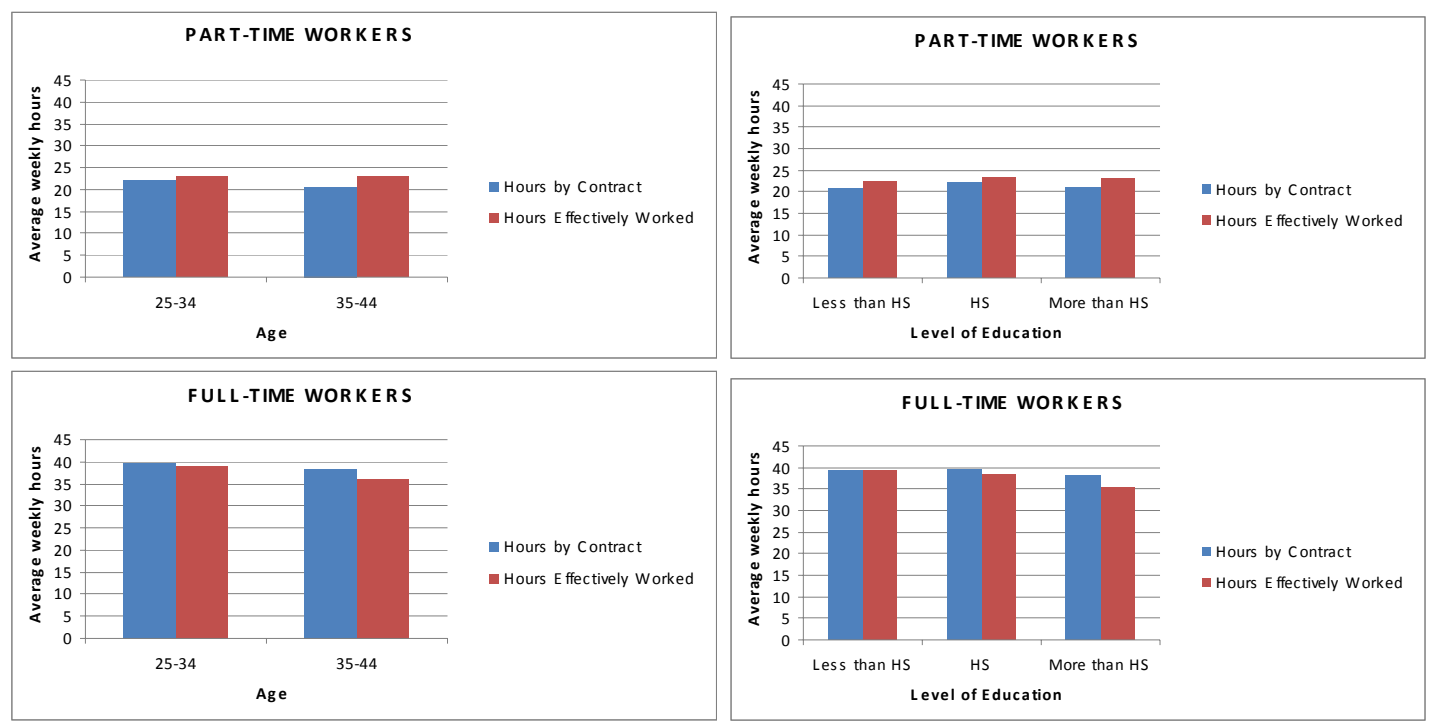

Note: The effective-contractual hours gap for PT workers is significantly different from the gap for FT workers at the $1 \%$ level across all age and education groups. The effective-contractual hours gap is always positive for PT workers and negative for FT workers and the difference between the two groups of workers grows with age and the level of education: is -1.34 hours when age is between 25-34, -4.83 hours at ages 35 to $45,-1.85$ hours for individuals with less than high school completed, -2.31 hours for those with a high school degree and -5.15 hours for college graduates. 


\section{Table 7}

Individual Attrition in Wage Change

(In parenthesis, as a \% of the total number of individuals in each category)

\begin{tabular}{|c|c|c|c|c|}
\hline & $\begin{array}{l}\text { Whole } \\
\text { sample }\end{array}$ & $\begin{array}{c}\text { Permanent } \\
\text { contract at } \\
\text { time } t-1\end{array}$ & $\begin{array}{c}\text { Fixed-term } \\
\text { contract at } \\
\text { time } t-1\end{array}$ & $\begin{array}{c}\text { Not } \\
\text { working at } \\
\text { time } t-1\end{array}$ \\
\hline Number of individuals* & $\begin{array}{c}962 \\
(1,27 \%)\end{array}$ & $\begin{array}{c}91 \\
(0.17 \%)\end{array}$ & $\begin{array}{c}537 \\
(1.07 \%)\end{array}$ & 334 \\
\hline Of which only work in FT & $\begin{array}{c}324 \\
(0.54 \%)\end{array}$ & $\begin{array}{c}0 \\
(0.00 \%)\end{array}$ & $\begin{array}{c}0 \\
(0.00 \%)\end{array}$ & 324 \\
\hline Of which switch to PT & $\begin{array}{c}638 \\
(3.87 \%)\end{array}$ & $\begin{array}{c}91 \\
(1.83 \%)\end{array}$ & $\begin{array}{c}537 \\
(3.82 \%)\end{array}$ & 10 \\
\hline And go to non-employment & 305 & 43 & 276 & 6 \\
\hline And return to FT within one period & 333 & 48 & 261 & 4 \\
\hline
\end{tabular}

*Number of individuals we drop in the hourly wage change specification because we do not observe them for at least two consecutive years in a given employment status 
Table 8

The Part-time Wage Growth Penalty

Women 24 to 45 years old: CSWH 1996-2006

\begin{tabular}{|c|c|c|c|c|c|c|c|c|c|c|c|}
\hline & $\begin{array}{l}\text { Pooled OLS } \\
\text { (Unadjusted) }\end{array}$ & $\begin{array}{c}\text { Pooled OLS } \\
\text { (Worker } \\
\text { controls) }\end{array}$ & $\begin{array}{l}\text { Fixed- } \\
\text { effects } \\
\text { (Worker } \\
\text { controls) }\end{array}$ & $\begin{array}{c}\text { Pooled OLS } \\
\text { (+ employer } \\
\text { characteristi } \\
\text { cs) }\end{array}$ & $\begin{array}{c}\text { Fixed- } \\
\text { effects } \\
\text { (+ employer } \\
\text { characteristi } \\
\text { cs) }\end{array}$ & $\begin{array}{l}\text { Pooled OLS } \\
\text { (+ industry) }\end{array}$ & $\begin{array}{c}\text { Fixed- } \\
\text { effects } \\
\text { (+ industry) }\end{array}$ & $\begin{array}{c}\text { Pooled OLS } \\
\text { (+employer } \\
\text { and } \\
\text { occupation } \\
\text { change) }\end{array}$ & $\begin{array}{c}\text { Fixed- } \\
\text { effects } \\
\text { (+employer } \\
\text { and } \\
\text { occupation } \\
\text { change) }\end{array}$ & $\begin{array}{c}\text { Pooled OLS } \\
\text { (+intermitte } \\
\text { ncies) }\end{array}$ & $\begin{array}{c}\text { Fixed- } \\
\text { effects } \\
\text { (+intermitte } \\
\text { ncies) }\end{array}$ \\
\hline & $(1)$ & $(2)$ & (3) & (4) & (5) & (6) & $(7)$ & $(8)$ & (9) & $(10)$ & (11) \\
\hline \multicolumn{12}{|c|}{ Panel A. Without Contract Type } \\
\hline & $\begin{array}{c}-.033^{* * *} \\
(.001)\end{array}$ & $\begin{array}{c}-.032 * * * \\
(.002)\end{array}$ & $\begin{array}{c}-.038 * * * \\
(.004)\end{array}$ & $\begin{array}{c}-.032 * * * \\
(.002)\end{array}$ & $\begin{array}{c}-.037 * * * \\
(.004)\end{array}$ & $\begin{array}{c}-.031^{* * *} \\
(.002)\end{array}$ & $\begin{array}{c}-.034 * * * \\
(.004)\end{array}$ & $\begin{array}{c}-.028 * * * \\
(.002)\end{array}$ & $\begin{array}{c}-.032 * * * \\
(.004)\end{array}$ & $\begin{array}{c}-.030 * * * \\
(.002)\end{array}$ & $\begin{array}{c}-.035^{* * *} \\
(.004)\end{array}$ \\
\hline \multicolumn{12}{|c|}{ Panel B. By Contract Type } \\
\hline $\begin{array}{l}\text { Fixed-term } \\
\text { contract at } \\
\text { time } t\end{array}$ & $\begin{array}{c}-.032 * * * \\
(.002)\end{array}$ & $\begin{array}{c}-.027 * * * \\
(.003)\end{array}$ & $\begin{array}{c}-.039 * * * \\
(.005)\end{array}$ & $\begin{array}{c}-.027 * * * \\
(.003)\end{array}$ & $\begin{array}{c}-.037 * * * \\
(.005)\end{array}$ & $\begin{array}{c}-.026 * * * \\
(.003)\end{array}$ & $\begin{array}{c}-.036^{* * *} \\
(.005)\end{array}$ & $\begin{array}{c}-.022 * * * \\
(.003)\end{array}$ & $\begin{array}{c}-.034^{* * *} \\
(.005)\end{array}$ & $\begin{array}{c}-.025^{* * *} \\
(.003)\end{array}$ & $\begin{array}{c}-.037 * * * \\
(.005)\end{array}$ \\
\hline $\begin{array}{l}\text { Permanent } \\
\text { contract at } \\
\text { time } t\end{array}$ & $\begin{array}{c}-.035^{* * *} \\
(.002)\end{array}$ & $\begin{array}{c}-.038 * * * \checkmark \\
(.003)\end{array}$ & $\begin{array}{c}-.029 * * * \checkmark \\
(.005)\end{array}$ & $\begin{array}{c}-.037 * * * \checkmark \\
(.003)\end{array}$ & $\begin{array}{c}-.031^{* * *} \\
(.005)\end{array}$ & $\begin{array}{c}-.036^{* * *} \checkmark \\
(.003)\end{array}$ & $\begin{array}{c}-.026^{* * *} \checkmark \\
(.005)\end{array}$ & $\begin{array}{c}-.033^{* * * \checkmark} \checkmark \\
(.003)\end{array}$ & $\begin{array}{c}-.025^{* * * \checkmark} \\
(.005)\end{array}$ & $\begin{array}{c}-.036^{* * * \checkmark} \checkmark \\
(.003)\end{array}$ & $\begin{array}{c}-.027 * * * \checkmark \\
(.005)\end{array}$ \\
\hline Sample size & 468,532 & 468,532 & 468,532 & 468,532 & 468,532 & 468,532 & 468,532 & 468,532 & 468,532 & 468,532 & 468,532 \\
\hline $\begin{array}{l}\# \\
\text { Individuals }\end{array}$ & 75,063 & 75,063 & 75,063 & 75,063 & 75,063 & 75,063 & 75,063 & 75,063 & 75,063 & 75,063 & 75,063 \\
\hline
\end{tabular}

Hourly earnings have been deflated using 2006 deflator and calculated with contractual hours. ***,**, * indicate significance at the $1 \%, 5 \%, 10 \%$ level (two-sided test). $\checkmark$ indicates that the difference of the estimated effects by type of contract is significant at the $10 \%$ level. UNADJUSTED: regressions control for year and province dummies. WORKER CONTROLS: part-time status, the number of consecutive years in part-time work, the type of contract at $t-1$, age, immigrant status, year, province, education,

level of experience in part-time and full-time jobs, the change in the level of experience, tenure, number of children, with children less than 3 and bigger than 6 dummies, and cohabiting status; EMPLOYER CHARACTERISTICS: occupation, number of workers and public sector. INDUSTRY: are two-digits industry dummies.

INTERMITTENCIES: the number of years not working relative to the number of years of potential experience. Potential experience is calculated as the difference between

the current year and the year of entry in the Social Security System. 


\section{Figure 3. The Cumulative Part-Time Penalty by Years in Part-Time Work PANEL A. Controlling for worker characteristics}

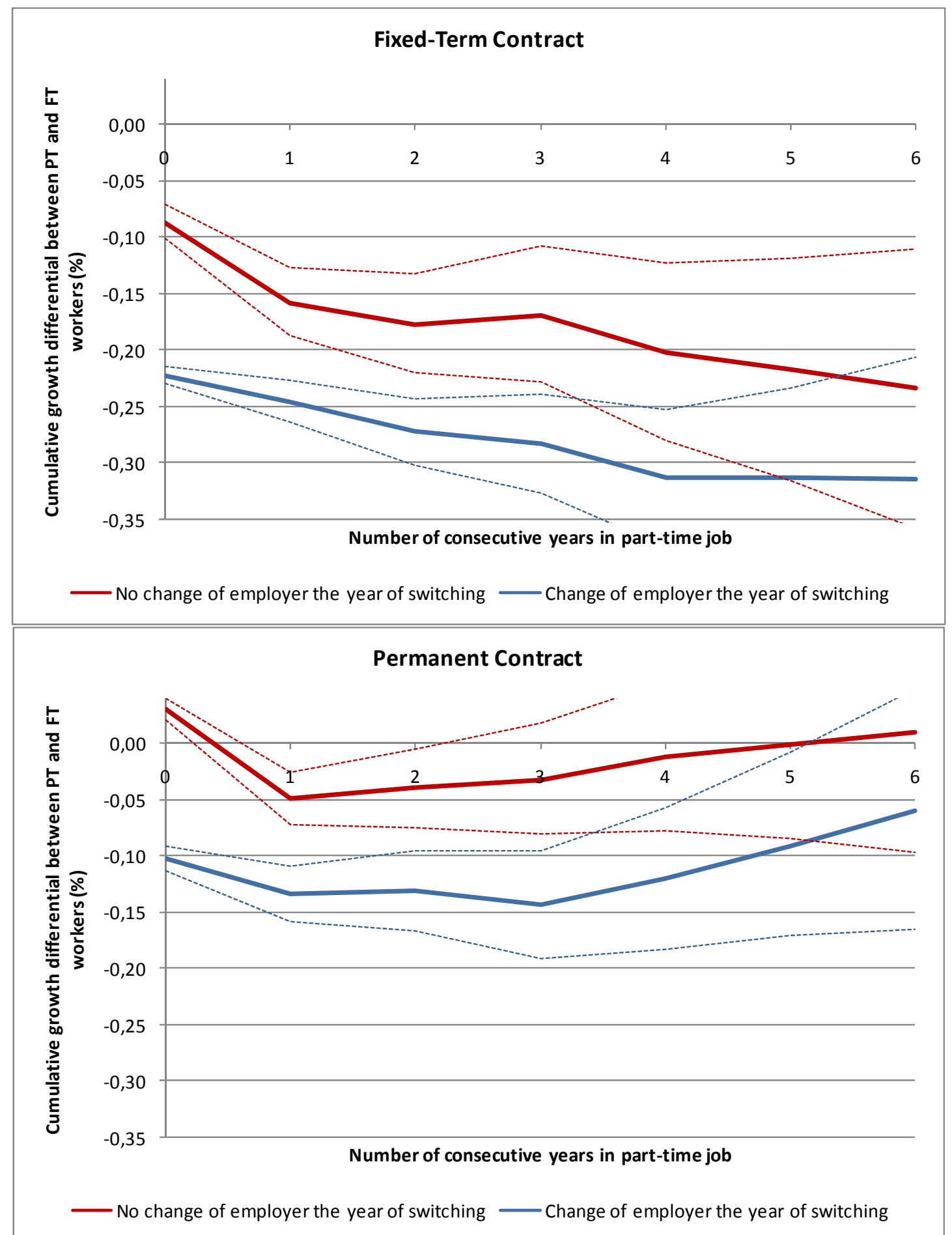

Note: Women 24 to 45 years old strongly attached to the labor market. Results come from a firstdifference specification with individual fixed effects, where the dependent variable is the one-year change in real hourly wages and controls are: part-time status, the number of consecutive years in part-time work, the type of contract at $\mathrm{t}-1$, age, year, province, education, level of experience in parttime and full-time jobs, the change in the level of experience, tenure, number of children, with children less than 3 and bigger than 6 dummies, cohabiting status, and immigrant status. Dashed lines represent the $5 \%$ confidence intervals of the part-time effect. The value for the first year in part-time job (switchers) comes from a regression where hours of work are effectively worked hours imputed using the Spanish Time Use Survey. 


\section{Figure 3. The Cumulative Part-Time Penalty by Years in Part-Time Work PANEL B. Controlling for worker, employer and job characteristics, and change of occupation and employer}

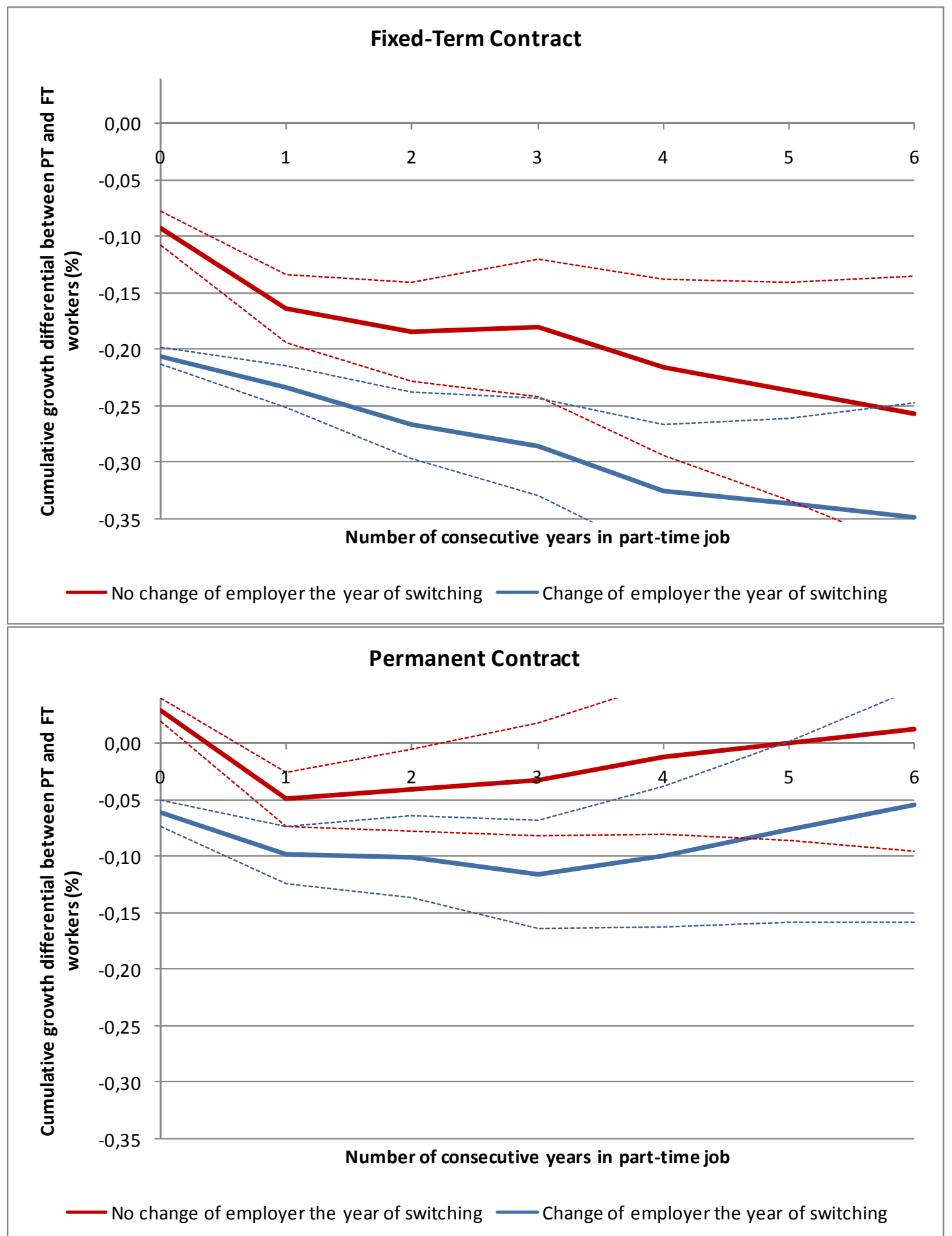

Note: Women 24 to 45 years old strongly attached to the labor market. Results come from a firstdifference specification with individual fixed effects, where the dependent variable is the one-year change in real hourly wages and controls are: worker characteristics + firm and job characteristics + change of occupation and change of employer. Dashed lines represent the $5 \%$ confidence intervals of the part-time effect. The value for the first year in part-time job (switchers) comes from a regression where hours of work are effectively worked hours imputed using the Spanish Time Use Survey. 
Table 9.A

The Part-time Wage Growth Penalty for Workers with Fixed-Term Contract at Time t-1, by Experience in Part-time Work

Women 24 to 45 years old

\begin{tabular}{|c|c|c|c|c|}
\hline & \multicolumn{2}{|l|}{$\begin{array}{l}\text { Fixed-effects } \\
\text { (Worker controls) }\end{array}$} & \multicolumn{2}{|c|}{$\begin{array}{l}\text { Fixed-effects } \\
\text { (Worker controls + employer } \\
\text { characteristics + change occupation or } \\
\text { employer) }\end{array}$} \\
\hline & Marginal effects & $\begin{array}{c}\text { Cumulative } \\
\text { effects }\end{array}$ & Marginal effects & $\begin{array}{c}\text { Cumulative } \\
\text { effects }\end{array}$ \\
\hline \multicolumn{5}{|c|}{ Number of consecutive years in part-time work if no change of employer the year of the switching } \\
\hline $\begin{array}{l}\text { The year of } \\
\text { switching }\end{array}$ & $\begin{array}{c}-.091^{* * *} \\
(.008)\end{array}$ & & $\begin{array}{c}-.097 * * * \\
(.008)\end{array}$ & \\
\hline At least 1 & $-.071 * * *$ & $-.071 * * *$ & $-.071 * * *$ & $-.071 * * *$ \\
\hline year & $(.007)$ & $(.007)$ & $(.007)$ & $(.007)$ \\
\hline At least 2 & $-.020 * *$ & $-.090 * * *$ & $-.022 * *$ & $-.092 * * *$ \\
\hline years & $(.010)$ & $(.014)$ & $(.010)$ & $(.014)$ \\
\hline At least 3 & .008 & $-.082 * * *$ & .004 & $-.088 * * *$ \\
\hline years & $(.014)$ & $(.023)$ & $(.014)$ & $(.022)$ \\
\hline At least 4 & $-.035^{*}$ & $-.115 * * *$ & $-.038 * *$ & $-.123 * * *$ \\
\hline years & (.019) & $(.032)$ & $(.018)$ & $(.032)$ \\
\hline At least 5 & -.018 & $-.131 * * *$ & -.023 & $-.144 * * *$ \\
\hline years & $(.020)$ & $(.042)$ & $(.020)$ & $(.041)$ \\
\hline At least 6 & -.018 & $-.147 * * *$ & -.023 & $-.164 * * *$ \\
\hline years & $(.020)$ & $(.055)$ & $(.020)$ & $(.053)$ \\
\hline \multicolumn{5}{|c|}{ Number of consecutive years in part-time work if change of employer the year of the switching } \\
\hline $\begin{array}{l}\text { The year of } \\
\text { switching }\end{array}$ & $-.251^{* * *}$ & & $-.230 * * *$ & \\
\hline At least 1 & $-.023 * * *$ & $-.023 * * *$ & $-.028 * * *$ & $-.028 * * *$ \\
\hline year & $(.005)$ & $(.005)$ & $(.005)$ & $(.005)$ \\
\hline At least 2 & $-.028 * * *$ & $-.050 * * *$ & $-.033 * * *$ & $-.061 * * *$ \\
\hline years & $(.008)$ & $(.011)$ & $(.008)$ & $(.011)$ \\
\hline At least 3 & -.011 & $-.061 * * *$ & $-.021^{*}$ & $-.080 * * *$ \\
\hline years & $(.011)$ & (.018) & $(.011)$ & $(.018)$ \\
\hline At least 4 & $-.032 * *$ & $-.091 * * *$ & $-.042 * * *$ & $-.119 * * *$ \\
\hline years & $(.016)$ & $(.027)$ & $(.016)$ & $(.026)$ \\
\hline At least 5 & -.000 & $-.091 * * *$ & -.013 & $-.131 * * *$ \\
\hline years & (.019) & $(.036)$ & $(.018)$ & $(.035)$ \\
\hline At least 6 & -.000 & $-.092 *$ & -.013 & $-.143^{* * *}$ \\
\hline years & $(.019)$ & $(.051)$ & $(.018)$ & $(.047)$ \\
\hline Sample size & 138,234 & 138,234 & 138,234 & 138,234 \\
\hline (\# individuals) & 48,217 & 48,217 & 48,217 & 48,217 \\
\hline
\end{tabular}

Hourly earnings have been deflated using 2006 deflator and estimated with contractual hours. ***, **, * indicate significance at the 1\%, 5\%, 10\% level (two-sided test). Women 24 to 45 years old strongly attached to the labor market. Results come from a first-difference specification with individual fixed effects, where the dependent variable is the one-year change in real hourly wages and controls are: WORKER CONTROLS: part-time status, the number of consecutive years in part-time work, the type of contract at $\mathrm{t}-1$, age, year, province, education, level of experience in part-time and full-time jobs, the change in the level of experience, tenure, number of children, with children less than 3 and bigger than 6 dummies, cohabiting status, and immigrant status; EMPLOYER CHARACTERISTICS: industry, occupation, number of workers and public sector. 
Table 9. B

The Part-time Wage Growth Penalty for Workers with Permanent Contract at time t-1, by Experience in Part-time Work

Women 24 to 45 years old

\begin{tabular}{|c|c|c|c|c|}
\hline & \multicolumn{2}{|l|}{$\begin{array}{l}\text { Fixed-effects } \\
\text { (Worker controls) }\end{array}$} & \multicolumn{2}{|c|}{$\begin{array}{l}\text { Fixed-effects } \\
\text { (Worker controls + employer } \\
\text { characteristics + change occupation or } \\
\text { employer) }\end{array}$} \\
\hline & Marginal effects & $\begin{array}{c}\text { Cumulative } \\
\text { effects }\end{array}$ & Marginal effects & $\begin{array}{c}\text { Cumulative } \\
\text { effects }\end{array}$ \\
\hline \multicolumn{5}{|c|}{ Number of consecutive years in part-time work if no change of employer the year of the switching } \\
\hline $\begin{array}{l}\text { The year of } \\
\text { switching }\end{array}$ & $\begin{array}{c}+.030 * * * \\
(.005)\end{array}$ & & $\begin{array}{c}+.029 * * * \\
(.004)\end{array}$ & \\
\hline At least 1 & $-.079 * * *$ & $-.079 * * *$ & $-.079 * * *$ & $-.079 * * *$ \\
\hline year & $(.006)$ & $(.006)$ & $(.006)$ & $(.006)$ \\
\hline At least 2 & .010 & $-.070 * * *$ & .009 & $-.071 * * *$ \\
\hline years & (.009) & $(.013)$ & $(.009)$ & $(.012)$ \\
\hline At least 3 & .008 & $-.062 * * *$ & .009 & $-.062 * * *$ \\
\hline years & $(.011)$ & $(.020)$ & $(.010)$ & $(.020)$ \\
\hline At least 4 & .020 & -.042 & .021 & -.042 \\
\hline years & $(.014)$ & $(.029)$ & $(.013)$ & $(.028)$ \\
\hline At least 5 & .011 & -.031 & .013 & -.029 \\
\hline years & $(.014)$ & $(.038)$ & $(.014)$ & $(.038)$ \\
\hline At least 6 & .011 & -.020 & .013 & -.017 \\
\hline years & $(.014)$ & $(.050)$ & $(.014)$ & (.049) \\
\hline \multicolumn{5}{|c|}{ Number of consecutive years in part-time work if change of employer the year of the switching } \\
\hline The year of & $-.108^{* * *}$ & & $-.064 * * *$ & \\
\hline switching & $(.006)$ & & $(.006)$ & \\
\hline At least 1 & $-.031 * * *$ & $-.031 * * *$ & $-.037 * * *$ & $-.037 * * *$ \\
\hline year & $(.007)$ & $(.007)$ & $(.006)$ & $(.006)$ \\
\hline At least 2 & .002 & $-.029 * * *$ & -.001 & $-.039 * * *$ \\
\hline years & $(.008)$ & $(.012)$ & $(.008)$ & $(.012)$ \\
\hline At least 3 & -.011 & $-.041^{* *}$ & -.015 & $-.054 * * *$ \\
\hline years & (.009) & $(.018)$ & $(.009)$ & $(.018)$ \\
\hline At least 4 & $.024 * *$ & -.017 & .017 & -.038 \\
\hline years & $(.013)$ & $(.026)$ & $(.012)$ & $(.026)$ \\
\hline At least 5 & $.030 * *$ & .012 & $.023 *$ & -.015 \\
\hline years & $(.014)$ & $(.036)$ & $(.014)$ & $(.034)$ \\
\hline At least 6 & $.030 * *$ & .043 & $.023 *$ & .007 \\
\hline years & $(.014)$ & $(.049)$ & $(.014)$ & $(.047)$ \\
\hline Sample size & 330,298 & 330,298 & 330,298 & 330,298 \\
\hline (\# individuals) & 54,093 & 54,093 & 54,093 & 54,093 \\
\hline
\end{tabular}

Hourly earnings have been deflated using 2006 deflator and estimated with contractual hours. ***, **,* indicate significance at the 1\%, 5\%, 10\% level (two-sided test). Women 24 to 45 years old strongly attached to the labor market. Results come from a first-difference specification with individual fixed effects, where the dependent variable is the one-year change in real hourly wages and controls are: WORKER CONTROLS: part-time status, the number of consecutive years in part-time work, the type of contract at t-1, age, year, province, education, level of experience in part-time and full-time jobs, the change in the level of experience, tenure, number of children, with children less than 3 and bigger than 6 dummies, cohabiting status, and immigrant status; EMPLOYER CHARACTERISTICS: industry, occupation, number of workers and public sector. 


\section{APPENDIX}

\section{(Not necessarily for publication)}




\section{Validation of the use of imputed hours}

We have conducted the following robustness test of the use of imputed hours. Given that the difference between effective and contract hours is lower (for both PT and FT workers) among workers younger than 35 years old than for those older than 34 years old (as shown in Figure 2 in the main text), we have re-estimated the final specification separately for the two age groups. If the switch from premium to penalty is the result of measurement error, we would expect to see a much larger difference between the biased and imputed results among the older sample (ages 35-44). Appendix Table A.2 shows this robustness test and confirms the validity of our correction. Indeed, the difference between the biased and corrected estimates is considerably greater for the older sample than the younger one. In addition, the difference in the correction of the measurement error between the older and the younger samples is greater among workers with fixed-term contract than those with permanent, which would be expected if employers have more leeway in under-reporting contractual hours among those in the secondary market.

\section{Re-estimation of the growth analysis using imputed wages}

In the growth analysis, an alternative correction for the differential measurement error in contractual hourly wages by PT status is to use imputed wages as we did in the levels analysis. Panel B in Appendix Table A.3 shows the estimates from the growth analysis using imputed wages. Our preferred estimates, FE with worker controls, are displayed in column 4 and show similar results to those found when the year of the change of PT status is dropped. Indeed, we find that there is a statistically significant PT penalty in growth for both types of contracts, and that the PT penalty in growth is higher and statistically so for women with a fixed-term contract than for those with a permanent one. In comparison, Panel A, which shows the growth estimates prior to applying any 
correction for the differential measurement error by PT status, deliver considerably smaller coefficients (and not always statistically significant for workers with permanent contracts).

\section{Endogeneity into type of contract}

Because type of contract may also be endogenous, we have explored the robustness of our results by estimating a fixed-effects two-stage least squares estimator (FE-2SLS hereafter). As instruments, we have tried two possible IVs, frequently used in Spain to correct for endogeneity by type of contract. First, following De la Rica, 2007, we have estimated the rate of fixed-term contracts by year, province, industry and age groups. This IV has been estimated using the Spanish Labor Force Survey FOR YEARS 19962006. ${ }^{50}$ Alternatively, following Barceló and Villanueva, 2010, we instrument the type of contract using regional variation in the amount, timing and target groups of subsidies given to firms to hire permanent workers (or convert fixed-term contracts into permanent ones). ${ }^{51}$ While we are aware of the potential issues with these two IVs, our purpose is not to claim that we solve the endogeneity problem per se, but instead to provide some robustness checks on our key findings.

Appendix Tables A.4 (level estimates) and A.5 (growth estimates) show our FE estimates and the two FE-2SLS estimates. In Table A.4, we find that correcting for endogeneity by type of contract increases the PT penalty of workers with a fixed-term contract by one fourth (from -23 to -29 log points), while leaving it unchanged to 9 log points or reducing it to 6 log points (depending on which IV is used) for workers with

\footnotetext{
${ }^{50}$ The estimate of the $I V$ in the first stage FE equation is positive and significant at the 1 percent confidence level.

${ }^{51}$ The estimate of the IV in the first stage FE is positive and statistically significant at the $1 \%$ confidence level.
} 
permanent contracts. ${ }^{52}$ Table A.4 shows a similar correction in terms of the wage growth. These results suggest that there is some positive selection into fixed-term PT contracts, and that not correcting by such type of selection, underestimates the PT penalty among this segment of the labor force. The underlying rationale seems to be that among FT workers, those who work in temporary jobs are those of lower productivity. However, the opposite seems to hold for PT workers suggesting that those with a temporary contract are trapped in such work arrangements, whereas those with permanent contracts select into those types of jobs (as their job stability is guaranteed).

\section{Employer fixed-effects estimators}

In addition, we have re-estimated our preferred specifications using employer-worker match fixed- effects estimators (shown in Table A.6). The idea here is to rule out the possibility that our results are driven by the selection of PT workers into firms that pay lower or that have lower wage growth. On average we have 3.4 year observations for each of the 173,514 firm-worker matches. We find that the PT penalty in levels decreases for workers in the secondary market, suggesting that workers with fixed-term contracts who switch to PT work are concentrated in low-paying employers. In contrast, for workers in the primary labor market the opposite is observed, implying that workers with permanent contracts who switch to PT work are those who work in highpaying employers. The growth specification shows that in both cases, controlling for employer fixed effects increases the penalty, suggesting that workers are in firms with higher wage growth. Notice however, that the main findings hold: There is a PT penalty in levels and in growth that is aggravated for workers in the secondary labor market.

\footnotetext{
${ }^{52}$ Note that a priori, it is unclear how the sign of the endogeneity bias would have affected the PT penalty as the relationship between unobserved heterogeneity and type of contract may differ across FT and PT status in the primary (permanent jobs) and secondary sector (temporary jobs).
} 


\section{Mothers versus non-mothers}

We have re-estimated our preferred specifications separately for mothers versus nonmothers (shown in Appendix Table A.7). If the results found thus far were mainly driven by mothers, then we could infer that the PT wage differential is more of a compensating differential for flexible work schedule than a penalty. The underlying assumption here is that non mothers working PT do so mainly involuntarily. Using the 1999-2009 Labor Force Survey, we find evidence of this. When restricting the sample to women 25 to 45 years old with no children in the household, we find that less than 7\% of those working PT reported doing so voluntarily because of family reasons, and as many as 70\% reported doing so involuntarily (33\% because they did not find a FT job and $37 \%$ because their job required them to do so). ${ }^{53}$

Table A.7 shows that the main findings of the paper hold for both sub-samples. We find that women working PT have lower wages than those working FT, and that this wage differential is considerably greater for women with fixed-term contracts (than those with permanent contract). These results hold regardless of whether women have children living in the household with them or not. Similar results are found for the wage growth specification when women work with a fixed-term contract. However, in the wage growth analysis, we find that the loss associated with PT work for women with permanent contracts is mainly driven by those without children, suggesting that for mothers no such penalty takes place.

\section{Omitted variable bias due to lack of information on non-labor income}

Unfortunately, the CSWH does not have information on non-labor income or spouse's earnings. This could generate an omitted variable bias that could be affecting the coefficients of interest. To address this potential concern, we have re-estimated the

\footnotetext{
53 An additional, $14 \%$ of these women work PT voluntarily because they were studying or they were sick.
} 
preferred specifications (both in levels and in growth) separately for women cohabiting with a male and those living alone (shown in Appendix Table A.8). The estimates in Appendix Table A.8 show findings for each of the two samples consistent with those reported earlier in the paper, suggesting that the presence of a spouse in the household (and therefore of spouse's earnings) does not seem to be affecting the main results of the paper. 
Table 1.A.

Estimation of the PT Penalty Fixed-Effects Estimation Dependent variable: Ln(real hourly wage) with imputed effective hours

\begin{tabular}{|c|c|c|c|c|c|c|}
\hline \multirow[b]{3}{*}{ Part-Time } & \multicolumn{3}{|c|}{ Pooled OLS } & \multicolumn{3}{|c|}{ Individual Fixed-Effects } \\
\hline & $\begin{array}{l}\text { Whole } \\
\text { sample }\end{array}$ & $\begin{array}{c}\text { Fixed-Term } \\
\text { Contract }\end{array}$ & $\begin{array}{c}\text { Permanent } \\
\text { Contract }\end{array}$ & $\begin{array}{l}\text { Whole } \\
\text { sample }\end{array}$ & $\begin{array}{c}\text { Fixed-Term } \\
\text { Contract }\end{array}$ & $\begin{array}{c}\text { Permanent } \\
\text { Contract }\end{array}$ \\
\hline & $\begin{array}{c}-.232 * * * \\
(.003)\end{array}$ & $\begin{array}{c}-.260 * * * \\
(.004)\end{array}$ & $\begin{array}{c}-.191 * * * \\
(.004)\end{array}$ & $\begin{array}{c}-.171^{* * *} \\
(.001)\end{array}$ & $\begin{array}{c}-.213^{* * *} \\
(.003)\end{array}$ & $\begin{array}{c}-.078^{* * *} \\
(.002)\end{array}$ \\
\hline Less than HS & .. & $\begin{array}{c}-.076^{* * *} \\
(.004)\end{array}$ & $\begin{array}{c}-.138 * * * \\
(.004)\end{array}$ & .. & .. & .. \\
\hline HS graduate & $\begin{array}{c}.050 * * * \\
(.002)\end{array}$ & $\begin{array}{c}-.045^{* * * *} \\
(.004)\end{array}$ & $\begin{array}{c}-.076^{* * * *} \\
(.004)\end{array}$ & .. & .. & .. \\
\hline More than HS & $\begin{array}{c}.110 * * * \\
(.003)\end{array}$ & .. & .. & .. & .. & .. \\
\hline Immigrant & $\begin{array}{c}.000 \\
(.004)\end{array}$ & $\begin{array}{c}.016^{* * *} \\
(.005)\end{array}$ & $\begin{array}{c}-.017 * * * \\
(.006)\end{array}$ & .. & .. & .. \\
\hline Experience & $\begin{array}{c}.015^{* * *} \\
(.000)\end{array}$ & $\begin{array}{c}.003^{* * *} \\
(.001)\end{array}$ & $\begin{array}{c}.023^{* * *} \\
(.000)\end{array}$ & $\begin{array}{c}.042 * * * \\
(.001)\end{array}$ & $\begin{array}{c}.046^{* * *} \\
(.002)\end{array}$ & $\begin{array}{c}.024^{* * *} \\
(.001)\end{array}$ \\
\hline Experience $^{2}$ & $\begin{array}{c}-.0003^{* * *} \\
(.000)\end{array}$ & $\begin{array}{c}.0001 \\
(.0001)\end{array}$ & $\begin{array}{c}-.0005^{* * *} \\
(.000)\end{array}$ & $\begin{array}{c}-.0009 * * * \\
(.000)\end{array}$ & $\begin{array}{c}-.001^{* * *} \\
(.000)\end{array}$ & $\begin{array}{c}-.0007^{* * *} \\
(.000)\end{array}$ \\
\hline $\begin{array}{l}\text { Permanent } \\
\text { contract }\end{array}$ & $\begin{array}{l}.000 \\
(.002)\end{array}$ & .. & .. & $\begin{array}{c}.009 * * * \\
(.001)\end{array}$ & .. & .. \\
\hline With children & $\begin{array}{c}-.026 * * * \\
(.003)\end{array}$ & $\begin{array}{c}-.018 * * * \\
(.004)\end{array}$ & $\begin{array}{c}-.032 * * * \\
(.004)\end{array}$ & $\begin{array}{c}-.032 * * * \\
(.003)\end{array}$ & $\begin{array}{l}-.014^{*} \\
(.008)\end{array}$ & $\begin{array}{c}-.025^{* * *} \\
(.003)\end{array}$ \\
\hline $\begin{array}{l}\text { With baby }(0- \\
6)\end{array}$ & $\begin{array}{c}.020 * * * \\
(.003)\end{array}$ & $\begin{array}{c}.020 * * * \\
(.004)\end{array}$ & $\begin{array}{c}.014^{* * *} \\
(.004)\end{array}$ & $\begin{array}{c}.008^{* * *} \\
(.002)\end{array}$ & $\begin{array}{c}.018^{* * *} \\
(.006)\end{array}$ & $\begin{array}{c}-.008 * * * \\
(.002)\end{array}$ \\
\hline Tenure & $\begin{array}{c}.006^{* * * *} \\
(.000)\end{array}$ & $\begin{array}{c}.004^{* * * *} \\
(.001)\end{array}$ & $\begin{array}{c}.004^{* * *} \\
(.000)\end{array}$ & $\begin{array}{c}-.0009 * * * \\
(.0002)\end{array}$ & $\begin{array}{c}-.015^{* * * *} \\
(.001)\end{array}$ & $\begin{array}{c}-.000 \\
(.000)\end{array}$ \\
\hline $\begin{array}{l}\text { Firm size (\# } \\
\text { workers) }\end{array}$ & $\begin{array}{c}.001^{* * * *} \\
(.000)\end{array}$ & $\begin{array}{c}.001^{* * *} \\
(.000)\end{array}$ & $\begin{array}{c}.001^{* * * *} \\
(.000)\end{array}$ & $\begin{array}{c}.001^{* * *} \\
(.000)\end{array}$ & $\begin{array}{c}.001^{* * *} \\
(.000)\end{array}$ & $\begin{array}{c}.001^{* * *} \\
(.000)\end{array}$ \\
\hline Civil servant & $\begin{array}{c}.155^{* * * *} \\
(.004)\end{array}$ & $\begin{array}{c}.196^{* * *} \\
(.005)\end{array}$ & $\begin{array}{c}.153^{* * * *} \\
(.005)\end{array}$ & $\begin{array}{c}.139 * * * \\
(.004)\end{array}$ & $\begin{array}{c}.150^{* * *} \\
(.006)\end{array}$ & $\begin{array}{c}.069 * * * \\
(.008)\end{array}$ \\
\hline $\begin{array}{l}\text { Change of } \\
\text { employer }\end{array}$ & $\begin{array}{c}-.016^{* * *} \\
(.001)\end{array}$ & $\begin{array}{c}-.026^{* * *} \\
(.002)\end{array}$ & $\begin{array}{c}-.006^{* * *} \\
(.002)\end{array}$ & $\begin{array}{c}-.014^{* * *} \\
(.001)\end{array}$ & $\begin{array}{c}-.028 * * * \\
(.002)\end{array}$ & $\begin{array}{c}-.012^{* * * *} \\
(.001)\end{array}$ \\
\hline $\begin{array}{l}\text { Change of } \\
\text { occupation }\end{array}$ & $\begin{array}{c}-.048 * * * \\
(.001)\end{array}$ & $\begin{array}{c}-.017 * * * \\
(.002)\end{array}$ & $\begin{array}{c}-.089 * * * \\
(.002)\end{array}$ & $\begin{array}{c}-.030 * * * \\
(.001)\end{array}$ & $\begin{array}{c}.003 \\
(.002)\end{array}$ & $\begin{array}{c}-.072^{* * *} \\
(.001)\end{array}$ \\
\hline Intermittency & $\begin{array}{c}-.196 * * * \\
(.027)\end{array}$ & $\begin{array}{c}-.054^{* *} \\
(.028)\end{array}$ & $\begin{array}{c}-.392 * * * \\
(.046)\end{array}$ & $\begin{array}{c}.006 \\
(.020)\end{array}$ & $\begin{array}{c}-.136^{* * * *} \\
(.031)\end{array}$ & $\begin{array}{c}.313 * * * \\
(.036)\end{array}$ \\
\hline Intermittency $^{2}$ & $\begin{array}{l}340 * * * \\
(.058)\end{array}$ & $\begin{array}{l}.118 * * \\
(.059)\end{array}$ & $\begin{array}{c}.402 * * * \\
(.107)\end{array}$ & $\begin{array}{c}.037 \\
(.037) \\
\end{array}$ & $\begin{array}{c}.212 * * * \\
(.058)\end{array}$ & $\begin{array}{c}-.637 * * * \\
(.064) \\
\end{array}$ \\
\hline Observations & 591,063 & 194,218 & 396,845 & 591,063 & 194,218 & 396,845 \\
\hline Individuals & 77,815 & 53,693 & 60,139 & 77,815 & 53,693 & 60,139 \\
\hline $\mathrm{R}^{2}$ & .44 & .35 & .47 & .37 & .29 & .32 \\
\hline Age dummies & YES & YES & YES & YES & YES & YES \\
\hline Province dum & YES & YES & YES & YES & YES & YES \\
\hline Ind. dummies & YES & YES & YES & YES & YES & YES \\
\hline $\begin{array}{l}\text { Occ. } \\
\text { dummies }\end{array}$ & YES & YES & YES & YES & YES & YES \\
\hline $\begin{array}{l}\text { *** Significan } \\
\text { contractual ho } \\
\text { Dataset. A ne } \\
\text { following con } \\
\text { education, nati } \\
\text { that indicate th } \\
\text { immigrant sta } \\
\text { INDUSTRY } 8 \\
\text { CHANGE OF } \\
\text { t-1. }\end{array}$ & $\begin{array}{l}\text { it } 1 \% \text { level. } \\
\text {, age, educa } \\
\text { ive number } \\
\text { ls: UNADJ } \\
\text { ality, provil } \\
\text { presence in } \\
\text {; EMPLOY } \\
\text { OCCUPATI } \\
\text { MPLOYER }\end{array}$ & $\begin{array}{l}\text { Iputed hours } \\
\text { n, two-digit i } \\
\text { dicates a pen } \\
\text { STED - year } \\
\text { o of residence } \\
\text { e household o } \\
\text { R CHARACT } \\
\text { J - two-digits } \\
\text { dummy indi }\end{array}$ & $\begin{array}{l}\text { ustry and oc } \\
\text { y for part-ti } \\
\text { id province } \\
\text { experience a } \\
\text { children less } \\
\text { RISTICS - } \\
\text { idustry dum } \\
\text { ing if the in }\end{array}$ & $\begin{array}{l}\text { wation using } \\
\text { morkers. E } \\
\text { mmies; WC } \\
\text { quadratic o } \\
\text { an } 6 \text { years o } \\
\text { mber of w } \\
\text { s and ten o } \\
\text { idual's emp }\end{array}$ & $\begin{array}{l}\text { e Spanish Tir } \\
\text { h set of regre } \\
\text { KERS CON } \\
\text { xperience, te } \\
\text { and a dumm } \\
\text { ers, public } \\
\text { ipation categc } \\
\text { er at year t is }\end{array}$ & $\begin{array}{l}\text { ours against } \\
\text { Use Survey } \\
\text { ions has the } \\
\text { OLS - age, } \\
\text { re, dummies } \\
\text { indicator for } \\
\text { tor dummy; } \\
\text { es dummies; } \\
\text { ifferent from }\end{array}$ \\
\hline
\end{tabular}


Table A.2

Estimation of the Part-Time

Pay Penalty, Different

methodologies

The Effect of Imputing Effectively Worked Hours across Age Groups

Dependent variable: Ln(real hourly wage)

\begin{tabular}{|c|c|c|c|}
\hline & Whole sample & $\begin{array}{l}\text { With fixed-term contract } \\
\text { at time } t\end{array}$ & $\begin{array}{c}\text { With permanent contract } \\
\text { at time } t\end{array}$ \\
\hline & (1) & $(2)$ & (3) \\
\hline \multicolumn{4}{|c|}{ PANEL A. USING CONTRACTUAL HOURS TO CALCULATE HOURLY WAGES } \\
\hline \multirow{3}{*}{ Pooled OLS } & \multicolumn{3}{|c|}{ Panel A1. Young: aged 25-34 } \\
\hline & $+.027 * * *$ & $+.027 * * *$ & $+.037 * * *$ \\
\hline & $(.003)$ & $(.004)$ & $(.004)$ \\
\hline \multirow{3}{*}{$\begin{array}{l}\text { Individual Fixed- } \\
\text { Effects }\end{array}$} & $+.083 * * *$ & $+.068 * * *$ & $+.131 * * *$ \\
\hline & $(.001)$ & $(.003)$ & $(.003)$ \\
\hline & \multicolumn{3}{|c|}{ Panel A2. Old: aged 35-45 } \\
\hline Pooled OLS & $\begin{array}{l}+.013^{* * *} \\
\quad(.005)\end{array}$ & $\begin{array}{l}+.011 \\
(.007)\end{array}$ & $\begin{array}{c}+.034 * * * \\
(.007)\end{array}$ \\
\hline Individual Fixed- & $+.079 * * *$ & $+.057 * * *$ & $+.119 * * *$ \\
\hline Effects & $(.002)$ & $(.005)$ & $(.004)$ \\
\hline
\end{tabular}

PANEL B. USING IMPUTED EFFECTIVE HOURS TO CALCULATE HOURLY WAGES

$\begin{array}{lc}\text { Pooled OLS } & -.056^{* * *} \\ & (.003) \\ \text { Individual Fixed- } & +.001 \\ \text { Effects } & (.002)\end{array}$

$\begin{array}{lc}\text { Pooled OLS } & -.335^{* * *} \\ & (.006) \\ \text { Individual Fixed- } & -.258^{* * *} \\ \text { Effects } & (.003)\end{array}$

Panel B1. Young: aged 25-34

$\begin{array}{lc}-.083^{* * *} & -.019 * * * \\ (.004) & (.005) \\ -.037 * * * & +.094^{* * *} \\ (.003) & (.003)\end{array}$

Panel B2. Old: aged 35-45

$\begin{array}{cc}-.376 * * * & -.280 * * * \\ (.009) & (.008) \\ -.316^{* * *} & -.161^{* * *} \\ (.006) & (.004)\end{array}$

Sample size 591,063 194,218 396,845

Hourly earnings have been deflated using 2006 deflator and calculated with contractual hours. ***, **, * indicate significance at the 1\%,5\%, 10\% level (two-sided test). $\checkmark$ indicates that the difference of the estimated effects between the before 2001 and after 2001 period is significant at the $10 \%$ level. UNADJUSTED: regressions control for year and province dummies. WORKER CONTROLS: part-time status, the number of consecutive years in part-time work, the type of contract at t-1, age, immigrant status, year, province, education, level of experience in part-time and full-time jobs, the change in the level of experience, tenure, number of children, with children less than 3 and bigger than 6 dummies, and cohabiting status; EMPLOYER CHARACTERISTICS: industry, occupation, number of workers and public sector. 
Table A.3

The Part-time Wage Growth Penalty

Pooled OLS and Individual Fixed Effects Specifications

Using Imputed Hours versus Using Contractual Hours to Calculate Hourly Wages

Women 24 to 45 years old: CSWH 1996-2006

\begin{tabular}{|c|c|c|c|c|c|}
\hline & $\begin{array}{l}\text { Pooled OLS } \\
\text { (Unadjusted) }\end{array}$ & $\begin{array}{l}\text { Pooled OLS } \\
\text { (Worker } \\
\text { controls) }\end{array}$ & $\begin{array}{c}\text { Fixed-effects } \\
\text { (Worker } \\
\text { controls) }\end{array}$ & $\begin{array}{l}\text { Pooled OLS } \\
\text { (+employer and } \\
\text { occupation } \\
\text { change) }\end{array}$ & $\begin{array}{c}\text { Fixed-effects } \\
\text { (+employer and } \\
\text { occupation } \\
\text { change+intermit } \\
\text { tences) }\end{array}$ \\
\hline & $(1)$ & $(2)$ & $(4)$ & $(11)$ & $(12)$ \\
\hline \multicolumn{6}{|c|}{ PANEL A. USING CONTRACTUAL HOURS TO COMPUTE HOURLY WAGES } \\
\hline & $\begin{array}{c}-.003^{* *} \\
(.001)\end{array}$ & $\begin{array}{c}-.016^{* * *} \\
(.002)\end{array}$ & $\begin{array}{c}-.013^{* * *} \\
(.002)\end{array}$ & $\begin{array}{c}-.016^{* * *} \\
(.002)\end{array}$ & $\begin{array}{c}-.013 * * * \\
(.002)\end{array}$ \\
\hline \multicolumn{6}{|c|}{ Panel A2. By Contract Type } \\
\hline $\begin{array}{l}\text { Fixed-term } \\
\text { contract at } \\
\text { time } t\end{array}$ & $\begin{array}{c}-.014 * * * \\
(.002)\end{array}$ & $\begin{array}{c}-.018^{* * * *} \\
(.002)\end{array}$ & $\begin{array}{c}-.018^{* * *} \\
(.003)\end{array}$ & $\begin{array}{c}-.018^{* * *} \\
(.002)\end{array}$ & $\begin{array}{c}-.016 * * * \\
(.003)\end{array}$ \\
\hline $\begin{array}{l}\text { Permanent } \\
\text { contract at } \\
\text { time t }\end{array}$ & $\begin{array}{c}+.004 * \checkmark \\
(.002)\end{array}$ & $\begin{array}{c}-.012 * * * \\
(.003)\end{array}$ & $\begin{array}{r}-.004 \checkmark \\
(.004)\end{array}$ & $\begin{array}{c}-.011 * * * \checkmark \\
(.003)\end{array}$ & $\begin{array}{c}-.004 \checkmark \\
(.004)\end{array}$ \\
\hline Sample size & 506,322 & 506,322 & 506,322 & 506,322 & 506,322 \\
\hline \# Individuals & 76,016 & 76,016 & 76,016 & 76,016 & 76,016 \\
\hline \multicolumn{6}{|c|}{ PANEL B. USING IMPUTED EFFECTIVE HOURS TO COMPUTE HOURLY WAGES } \\
\hline & $\begin{array}{c}-.051 * * * \\
(.001)\end{array}$ & $\begin{array}{c}-.059 * * * \\
(.002)\end{array}$ & $\begin{array}{c}-.062 * * * \\
(.003)\end{array}$ & $\begin{array}{c}-.058 * * * \\
(.002)\end{array}$ & $\begin{array}{c}-.059 * * * \\
(.003)\end{array}$ \\
\hline \multicolumn{6}{|c|}{ Panel B2. By Contract Type } \\
\hline $\begin{array}{l}\text { Fixed-term } \\
\text { contract at } \\
\text { time } t\end{array}$ & $\begin{array}{c}-.077^{* * * *} \\
(.002)\end{array}$ & $\begin{array}{c}-.073^{* * *} \\
(.003)\end{array}$ & $\begin{array}{c}-.084 * * * \\
(.003)\end{array}$ & $\begin{array}{c}-.073 * * * \\
(.003)\end{array}$ & $\begin{array}{c}-.079 * * * \\
(.003)\end{array}$ \\
\hline $\begin{array}{l}\text { Permanent } \\
\text { contract at } \\
\text { time } t\end{array}$ & $\begin{array}{c}-.023 * * * \checkmark \\
(.002)\end{array}$ & $\begin{array}{c}-.026 * * * \checkmark \\
(.003)\end{array}$ & $\begin{array}{c}-.013 * * * \checkmark \\
(.004)\end{array}$ & $\begin{array}{c}-.025^{* * *} \checkmark \\
(.003)\end{array}$ & $\begin{array}{c}-.011 * \checkmark \\
(.004)\end{array}$ \\
\hline Sample size & 506,322 & 506,322 & 506,322 & 506,322 & 506,322 \\
\hline \# Individuals & 76,016 & 76,016 & 76,016 & 76,016 & 76,016 \\
\hline \multicolumn{6}{|c|}{$\begin{array}{l}\text { Hourly earnings have been deflated using } 2006 \text { deflator and calculated with contractual hours. } * * *, * *, * \\
\text { indicate significance at the } 1 \%, 5 \%, 10 \% \text { level (two-sided test). } \checkmark \text { indicates that the difference of the } \\
\text { estimated effects by type of contract is significant at the } 10 \% \text { level. UNADJUSTED: regressions control } \\
\text { for year and province dummies. WORKER CONTROLS: part-time status, the number of consecutive } \\
\text { years in part-time work, the type of contract at t-1, age, immigrant status, year, province, education, level } \\
\text { of experience in part-time and full-time jobs, the change in the level of experience, tenure, number of } \\
\text { children, with children less than } 3 \text { and bigger than } 6 \text { dummies, and cohabiting status; EMPLOYER } \\
\text { CHARACTERISTICS: occupation, number of workers and public sector. INDUSTRY: are two-digits } \\
\text { industry dummies. INTERMITTENCIES: the number of years not working relative to the number of } \\
\text { years of potential experience. Potential experience is calculated as the difference between the current } \\
\text { year and the year of entry in the Social Security System. }\end{array}$} \\
\hline
\end{tabular}


Table A.4

Estimation of the Part-Time Pay Penalty, FE-2SLS

Dependent variable: Ln(real hourly wage)

Women 24 to 45 years old

\begin{tabular}{|c|c|c|c|}
\hline & Unadjusted & Worker controls & $\begin{array}{l}\text { Worker controls + employer } \\
\text { characteristics }+ \text { change } \\
\text { occupation or employer }+ \\
\text { intermittencies }\end{array}$ \\
\hline \multicolumn{4}{|c|}{ Panel A: With fixed-term contracts (number of observations: 194,218$)$} \\
\hline Fixed- effects & $\begin{array}{c}-.237^{* * *} \\
(.003)\end{array}$ & $\begin{array}{c}-.230 * * * \\
(.003)\end{array}$ & $\begin{array}{c}-.213 * * * \\
(.003)\end{array}$ \\
\hline $\begin{array}{l}\text { FE- 2SLS } \\
\text { (De la Rica, 2007) }\end{array}$ & $\begin{array}{c}-.316^{* * * *} \\
(.004)\end{array}$ & $\begin{array}{c}-.285^{* * * *} \\
(.004)\end{array}$ & $\begin{array}{c}-.270 * * * \\
(.004)\end{array}$ \\
\hline $\begin{array}{l}\text { FE- 2SLS } \\
(\mathrm{BV}, 2010)\end{array}$ & $\begin{array}{c}-.312 * * * \\
(.005)\end{array}$ & $\begin{array}{c}-.287 * * * \\
(.005)\end{array}$ & $\begin{array}{c}-.272 * * * \\
(.005)\end{array}$ \\
\hline $\begin{array}{l}\text { Fixed- } \\
\text { Effects }\end{array}$ & $\begin{array}{r}\text { I C: With permanen } \\
-.095^{* * *} \\
(.003)\end{array}$ & $\begin{array}{r}\text { (number of observa } \\
-.087^{* * *} \\
(.003)\end{array}$ & $\begin{array}{c}-.078^{* * *} \\
(.002)\end{array}$ \\
\hline $\begin{array}{l}\text { FE- 2SLS } \\
\text { (De la Rica, 2007) }\end{array}$ & $\begin{array}{c}-.080 * * * \\
(.003)\end{array}$ & $\begin{array}{c}-.091 * * * \\
(.003)\end{array}$ & $\begin{array}{c}-.075 * * * \\
(.003)\end{array}$ \\
\hline $\begin{array}{l}\text { FE- 2SLS } \\
(\mathrm{BV}, 2010)\end{array}$ & $\begin{array}{c}-.058 * * * \\
(.005)\end{array}$ & $\begin{array}{c}-.062 * * * \\
(.005)\end{array}$ & $\begin{array}{c}-.048 * * * \\
(.005)\end{array}$ \\
\hline
\end{tabular}

\footnotetext{
*** Significant at $1 \%$ level. A negative number indicates a penalty for part-time workers. Each set of regressions has the following controls: UNADJUSTED - year and province dummies; WORKERS CONTROLS - age, education, nationality, province of residence, experience and quadratic of experience, tenure, dummies that indicate the presence in the household of children and of children less than 6 years old, and a dummy indicator for immigrant status; EMPLOYER CHARACTERISTICS number of workers, public sector dummy; INDUSTRY \& OCCUPATION - two-digits industry dummies and ten occupation categories dummies; CHANGE OF EMPLOYER - a dummy indicating if the individual's employer at year $t$ is different from t1; INTERMITTENCIES: the number of years not working relative to the number of years of potential experience. Potential experience is calculated as the difference between the current year and the year of entry in the Social Security System.

2SLS: in the first step, the type of contract at year $t$ is regressed against the set of worker and employer controls, province and year dummies and the level of unemployment and GDP growth at the province level, and the IV. The first IV is the rate of fixedterm contracts by year, province, industry and age groups. While the second IV is the monetary subsidy for the conversion of a fixed-term contract into a permanent one according to age, year, region and gender of the individual. In the first step regression, the coefficient of the IV was positive and significant at the $1 \%$ confidence level.
} 
Table A.5

The Part-time Wage Growth Penalty

FE - 2SLS

Women 24 to 45 years old: CSWH 1996-2006

\begin{tabular}{|c|c|c|c|c|c|c|c|c|c|}
\hline \multirow[t]{2}{*}{ Covariates } & \multicolumn{3}{|c|}{ Unadjusted } & \multicolumn{3}{|c|}{ Worker controls } & \multicolumn{3}{|c|}{$\begin{array}{l}\text { (+employer and occupation } \\
\text { change+intermittencies) }\end{array}$} \\
\hline & $\begin{array}{l}\text { Fixed- } \\
\text { Effects }\end{array}$ & $\begin{array}{l}\text { FE-2SLS } \\
\text { (De la Rica, } \\
\text { 2007) }\end{array}$ & $\begin{array}{l}\text { FE-2SLS } \\
(\mathrm{BV}, 2010)\end{array}$ & Fixed-effects & $\begin{array}{l}\text { FE-2SLS } \\
\text { (De la Rica, } \\
\text { 2007) }\end{array}$ & $\begin{array}{l}\text { FE-2SLS } \\
(\mathrm{BV}, 2010)\end{array}$ & Fixed-effects & $\begin{array}{l}\text { FE-2SLS } \\
\text { (De la Rica, } \\
\text { 2007) }\end{array}$ & $\begin{array}{c}\text { FE-2SLS } \\
(\mathrm{BV}, 2010)\end{array}$ \\
\hline & (3) & $(2)$ & (3) & (4) & (5) & (6) & (10) & (9) & (10) \\
\hline $\begin{array}{l}\text { Fixed-term } \\
\text { contract at time } \\
\text { t }\end{array}$ & $\begin{array}{l}-.032^{* * *} \\
(.003)\end{array}$ & $\begin{array}{c}-.042 * * * \\
(.007)\end{array}$ & $\begin{array}{c}-.051^{* * *} \\
(.010)\end{array}$ & $\begin{array}{l}-.039 * * * \\
(.005)\end{array}$ & $\begin{array}{l}-.045^{* * *} \\
(.008)\end{array}$ & $\begin{array}{l}-.049 * * * \\
(.010)\end{array}$ & $\begin{array}{c}-.037^{* * *} \\
(.005)\end{array}$ & $\begin{array}{c}-.041^{* * *} \\
(.008)\end{array}$ & $\begin{array}{l}-.045^{* * *} \\
(.010)\end{array}$ \\
\hline $\begin{array}{l}\text { Permanent } \\
\text { contract at time } \\
\text { t }\end{array}$ & $\begin{array}{c}-.034 * * * \\
(.002)\end{array}$ & $\begin{array}{c}-.014 * * * \\
(.005)\end{array}$ & $\begin{array}{r}-.011 \checkmark \\
(.007)\end{array}$ & $\begin{array}{l}-.029 * * * \checkmark \\
(.005)\end{array}$ & $\begin{array}{c}-.021^{* * * \checkmark} \checkmark \\
(.008)\end{array}$ & $\begin{array}{c}-.023 * * \checkmark \\
(.011)\end{array}$ & $\begin{array}{l}-.027 * * * \checkmark \\
(.005)\end{array}$ & $\begin{array}{l}-.020 * * * \checkmark \\
(.008)\end{array}$ & $\begin{array}{c}-.019 * \checkmark \\
(.011)\end{array}$ \\
\hline
\end{tabular}

Hourly earnings have been deflated using 2006 deflator and calculated with contractual hours. ***, **, * indicate significance at the $1 \%, 5 \%, 10 \%$ level (two-sided test). $\checkmark$ indicates that the difference of the estimated effects by type of contract is significant at the $10 \%$ level. UNADJUSTED: regressions control for year and province dummies. WORKER CONTROLS: part-time status, the number of consecutive years in part-time work, the type of contract at t- 1 , age, immigrant status, year, province, education, level of experience in part-time and full-time jobs, the change in the level of experience, tenure, number of children, with children less than 3 and bigger than 6 dummies, and cohabiting status; EMPLOYER CHARACTERISTICS: occupation, number of workers and public sector. INDUSTRY: are two-digits industry dummies.

INTERMITTENCIES: the number of years not working relative to the number of years of potential experience. Potential experience is calculated as the difference between the current year and the year of entry in the Social Security System. . 
Table A.6

The Part-time Wage Penalty

Women 24 to 45 years old

Individuals' FE versus Individuals and Employers' FE

\begin{tabular}{|c|c|c|c|c|}
\hline & \multicolumn{2}{|c|}{ LEVELS ANALYSIS* } & \multicolumn{2}{|c|}{ GROWTH ANALYSIS ${ }^{\phi}$} \\
\hline & $\begin{array}{l}\text { Individual Fixed-effects } \\
\text { (Worker controls) }\end{array}$ & $\begin{array}{c}\text { Individual Fixed-effects } \\
\text { (Worker controls + employer } \\
\text { characteristics+ industry) }\end{array}$ & $\begin{array}{l}\text { Individual Fixed-effects } \\
\text { (Worker controls) }\end{array}$ & $\begin{array}{c}\text { Individual Fixed-effects } \\
\text { (Worker controls + employer characteristics+ } \\
\text { industry) }\end{array}$ \\
\hline & (1) & $(2)$ & (3) & $(4)$ \\
\hline & \multicolumn{4}{|c|}{ Panel A. Without contract type } \\
\hline \multirow[t]{2}{*}{ FE } & $-.187 * * *$ & $-.171^{* * *}$ & $-.038^{* * *}$ & $-.034 * * *$ \\
\hline & $(.001)$ & $(.001)$ & $(.004)$ & $(.004)$ \\
\hline \multirow[t]{3}{*}{ Individual and employer FE } & $-.127 * * *$ & $-.114^{* * *}$ & $-.055^{* * *}$ & $-.056^{* * *}$ \\
\hline & $(.002)$ & $(.002)$ & $(.006)$ & $(.006)$ \\
\hline & \multicolumn{4}{|c|}{$\begin{array}{l}\text { Panel B. By contract type } \\
\text { Fixed-term contract at time } t\end{array}$} \\
\hline \multirow[t]{2}{*}{ FE } & $-.287 * * *$ & $-.272 * * *$ & $-.039 * * *$ & $-.036 * * *$ \\
\hline & $(.005)$ & $(.005)$ & $(.005)$ & $(.005)$ \\
\hline \multirow[t]{3}{*}{ Individual and employer FE } & $-.149 * * *$ & $-.141^{* * *}$ & $-.069 * * *$ & $-.068 * * *$ \\
\hline & $(.003)$ & $(.003)$ & $(.007)$ & $(.007)$ \\
\hline & \multicolumn{4}{|c|}{ Permanent contract at time $t$} \\
\hline \multirow[t]{2}{*}{ FE } & $-.062^{* * *}$ & $-.048 * * *$ & $-.029 * * * \checkmark$ & $-.026 * * * \checkmark$ \\
\hline & $(.005)$ & $(.005)$ & $(.005)$ & $(.005)$ \\
\hline \multirow[t]{2}{*}{ Individual and employer FE } & $-.105^{* * *}$ & $-.089 * * *$ & $-.043 * * * \checkmark$ & $-.044 * * * \checkmark$ \\
\hline & $(.002)$ & $(.089)$ & $(.007)$ & $(.007)$ \\
\hline Sample size & 591,063 & 591,063 & 468,532 & 468,532 \\
\hline (\# individuals) & 77,815 & 77,815 & 75,063 & 75,063 \\
\hline (\# of firm-individual matches) & 173,514 & & 131,712 & 131,712 \\
\hline
\end{tabular}

"Specification that uses imputed effective hours to calculate hourly wages. $\$$ Specification that uses contractWhmaiual hours to compute hourly wages and drops observations of the year of switching. Hourly earnings have been deflated using 2006 deflator and calculated with contractual hours. $* * *, * *, *$ indicate significance at the $1 \%, 5 \%, 10 \%$ level (two-sided test). $\checkmark$ indicates that the difference of the estimated effects between women with and without children is significant at the $10 \%$ level. UNADJUSTED: regressions control for year and province dummies. WORKER CONTROLS: part-time status, the number of consecutive years in part-time work, the type of contract at t-1, age, immigrant status, year, province, education, level of experience in part-time and full-time jobs, the change in the level of experience, tenure, number of children, with children less than 3 and bigger than 6 dummies, and cohabiting status; EMPLOYER CHARACTERISTICS: industry, occupation, number of workers and public sector. 
Table A.7

The Part-time Wage Growth Penalty

Women 24 to 45 years old

Mothers versus Women without Children

\begin{tabular}{|c|c|c|c|c|}
\hline & \multicolumn{2}{|c|}{ LEVELS ANALYSIS* } & \multicolumn{2}{|c|}{ GROWTH ANALYSIS ${ }^{\phi}$} \\
\hline & $\begin{array}{l}\text { Individual Fixed-effects } \\
\text { (Worker controls) }\end{array}$ & $\begin{array}{l}\text { Individual Fixed-effects } \\
\text { (Worker controls + employer } \\
\text { characteristics+ industry) }\end{array}$ & $\begin{array}{l}\text { Individual Fixed-effects } \\
\text { (Worker controls) }\end{array}$ & $\begin{array}{c}\text { Individual Fixed-effects } \\
\text { (Worker controls + employer characteristics+ } \\
\text { industry) }\end{array}$ \\
\hline & (1) & $(2)$ & (3) & $(4)$ \\
\hline & & & contract type & \\
\hline Women without children & $\begin{array}{l}-.192 * * * \\
(.002)\end{array}$ & $\begin{array}{c}-.176^{* * *} \\
(.002)\end{array}$ & $\begin{array}{c}-.045^{* * *} \\
(.004)\end{array}$ & $\begin{array}{c}-.041^{* * * *} \\
(.004)\end{array}$ \\
\hline \multirow[t]{2}{*}{ Women with children } & $\begin{array}{l}-.174 * * * \checkmark \\
\quad(.003)\end{array}$ & $\begin{array}{l}-.157 * * * \checkmark \\
(.003)\end{array}$ & $\begin{array}{c}-.015 * \checkmark \\
(.008)\end{array}$ & $\begin{array}{l}-.013 \checkmark \\
(.008)\end{array}$ \\
\hline & \multicolumn{4}{|c|}{$\begin{array}{l}\text { Panel B. By contract type } \\
\text { Fixed-term contract at time } t\end{array}$} \\
\hline Women without children & $\begin{array}{c}-.226^{* * *} \\
(.003)\end{array}$ & $\begin{array}{c}-.210^{* * *} \\
(.003)\end{array}$ & $\begin{array}{c}-.044 * * * \\
(006)\end{array}$ & $\begin{array}{l}-.038^{* * *} \\
(006)\end{array}$ \\
\hline \multirow[t]{2}{*}{ Women with children } & $\begin{array}{c}-.245^{* * * \checkmark} \checkmark \\
(.007)\end{array}$ & $\begin{array}{c}-.224 * * * \checkmark \\
(.006)\end{array}$ & $\begin{array}{c}-.024^{* *} \\
(.011)\end{array}$ & $\begin{array}{l}-.023^{* *} \\
(.011)\end{array}$ \\
\hline & \multicolumn{4}{|c|}{ Permanent contract at time $t$} \\
\hline Women without children & $\begin{array}{c}-.081^{* * *} \\
(.003)\end{array}$ & $\begin{array}{l}-.072^{* * *} \\
(.003)\end{array}$ & $\begin{array}{c}-.038^{* * *} \\
(.006)\end{array}$ & $\begin{array}{l}-.038^{* * *} \\
(.006)\end{array}$ \\
\hline Women with children & $\begin{array}{c}-.096 * * * \checkmark \\
(.004)\end{array}$ & $\begin{array}{c}-.087 * * * \checkmark \\
(.004)\end{array}$ & $\begin{array}{l}.001 \checkmark \\
(.010)\end{array}$ & $\begin{array}{l}.001 \checkmark \\
(.010)\end{array}$ \\
\hline Sample size & 591,063 & 591,063 & 468,532 & 468,532 \\
\hline With children & $133,002(22.5 \%)$ & $133,002(22.5 \%)$ & $105,482(22.5 \%)$ & $105,482(22.5 \%)$ \\
\hline (\# individuals) & 77,815 & 77,815 & 75,063 & 75,063 \\
\hline With children & $26,312(33.8 \%)$ & $26,312(33.8 \%)$ & $24,627(32.8 \%)$ & $24,627(32.8 \%)$ \\
\hline
\end{tabular}

"Specification that uses imputed effective hours to calculate hourly wages. $\$$ Specification that uses contractual hours to compute hourly wages and drops observations of the year of switching. Hourly earnings have been deflated using 2006 deflator and calculated with contractual hours. $* * *, * *, *$ indicate significance at the $1 \%, 5 \%, 10 \%$ level (two-sided test). $\checkmark$ indicates that the difference of the estimated effects between women with and without children is significant at the $10 \%$ level. UNADJUSTED: regressions control for year and province dummies. WORKER CONTROLS: part-time status, the number of consecutive years in part-time work, the type of contract at t-1, age, immigrant status, year, province, education, level of experience in part-time and full-time jobs, the change in the level of experience, tenure, number of children, with children less than 3 and bigger than 6 dummies, and cohabiting status; EMPLOYER CHARACTERISTICS: industry, occupation, number of workers and public sector. 
Table A.8

The Part-time Wage Growth Penalty

Women 24 to 45 years old

Women Cohabiting and Lone Women

\begin{tabular}{|c|c|c|c|c|}
\hline & \multicolumn{2}{|c|}{ LEVELS ANALYSIS* } & \multicolumn{2}{|c|}{ GROWTH ANALYSIS $\$$} \\
\hline & $\begin{array}{l}\text { Individual Fixed-effects } \\
\text { (Worker controls) }\end{array}$ & $\begin{array}{l}\text { Individual Fixed-effects } \\
\text { (Worker controls + employer } \\
\text { characteristics+ industry) }\end{array}$ & $\begin{array}{l}\text { Individual Fixed-effects } \\
\text { (Worker controls) }\end{array}$ & $\begin{array}{c}\text { Individual Fixed-effects } \\
\text { (Worker controls + employer characteristics+ } \\
\text { industry) }\end{array}$ \\
\hline & (1) & (2) & (3) & (4) \\
\hline \multirow[b]{2}{*}{ Cohabiting women } & & & contract type & \\
\hline & $\begin{array}{c}-.187 * * * \\
(.002)\end{array}$ & $\begin{array}{c}-.171^{* * *} \\
(.003)\end{array}$ & $\begin{array}{c}-.036 * * * \\
(.004)\end{array}$ & $\begin{array}{c}-.033^{* * *} \\
(.004)\end{array}$ \\
\hline \multirow[t]{2}{*}{ Lone women } & $\begin{array}{c}-.186^{* * *} \\
(.004)\end{array}$ & $\begin{array}{c}-.171^{* * *} \\
(.004)\end{array}$ & $\begin{array}{c}-.044^{* * *} \\
(.008)\end{array}$ & $\begin{array}{c}-.042^{* * *} \\
(008)\end{array}$ \\
\hline & \multicolumn{4}{|c|}{$\begin{array}{l}\text { Panel B. By contract type } \\
\text { Fixed-term contract at time } t\end{array}$} \\
\hline Cohabiting women & $\begin{array}{l}-.232 * * * \\
(.003)\end{array}$ & $\begin{array}{l}-.214^{* * *} \\
(.003)\end{array}$ & $\begin{array}{c}-.038^{* * *} \\
(.005)\end{array}$ & $\begin{array}{c}-.035^{* * *} \\
(.005)\end{array}$ \\
\hline \multirow[t]{2}{*}{ Lone women } & $\begin{array}{c}-.218^{* * * \checkmark} \\
(.007)\end{array}$ & $\begin{array}{c}-.205^{* * *} \\
(.007)\end{array}$ & $\begin{array}{c}-.042^{* * *} \\
(.011)\end{array}$ & $\begin{array}{c}-.041^{* * *} \\
(.010)\end{array}$ \\
\hline & \multicolumn{4}{|c|}{ Permanent contract at timet $t$} \\
\hline Cohabiting women & $\begin{array}{c}-.085 * * * \\
(.003)\end{array}$ & $\begin{array}{c}-.077^{* * *} \\
(.003)\end{array}$ & $\begin{array}{c}-.028^{* * *} \\
(.005)\end{array}$ & $\begin{array}{c}-.025^{* * *} \\
(.003)\end{array}$ \\
\hline Lone women & $\begin{array}{c}-.098^{* * * *} \\
(.007)\end{array}$ & $\begin{array}{c}-.085 * * * \\
(.007)\end{array}$ & $\begin{array}{c}-.037^{* * * *} \\
(.010)\end{array}$ & $\begin{array}{c}-.037 * * * \\
(.010)\end{array}$ \\
\hline Sample size & 591,063 & 591,063 & 468,532 & 468,532 \\
\hline Cohabiting & $479,694(81.2 \%)$ & $479,694(81.2 \%)$ & $379,796(81.1 \%)$ & $379,796(81.1 \%)$ \\
\hline (\# individuals) & 77,815 & 77,815 & 75,063 & 75,063 \\
\hline Cohabiting & $63,301(81.3 \%)$ & $63,301(81.3 \%)$ & $60,949(81.2 \%)$ & $60,949(81.2 \%)$ \\
\hline
\end{tabular}

* Specification that uses imputed effective hours to calculate hourly wages. $\$$ Specification that uses contractual hours to compute hourly wages and drops observations of the year of switching. Hourly earnings have been deflated using 2006 deflator and calculated with contractual hours. ***,**,* indicate significance at the $1 \%, 5 \%, 10 \%$ level (two-sided test). $\checkmark$ indicates that the difference of the estimated effects between women with and without children is significant at the $10 \%$ level. UNADJUSTED: regressions control for year and province dummies. WORKER CONTROLS: part-time status, the number of consecutive years in part-time work, the type of contract at $\mathrm{t}-1$, age, immigrant status, year, province, education, level of experience in part-time and full-time jobs, the change in the level of experience, tenure, number of children, with part-time work, the type of contract at t-1, age, immigrant status, year, province, education, level of experience in part-time and full-time jobs, the change in the level of
children less than 3 and bigger than 6 dummies, and cohabiting status; EMPLOYER CHARACTERISTICS: industry, occupation, number of workers and public sector. 